\title{
Reaction path models of magmatic gas scrubbing
}

\author{
Rossella Di Napoli a,*, Alessandro Aiuppa ${ }^{\text {a,b }}$, Baldur Bergsson ${ }^{\text {a,c }}$, Evgenia Ilyinskaya ${ }^{\text {, }}$ \\ Melissa Anne Pfeffer ${ }^{\mathrm{c}}$, Sylvía Rakel Guðjónsdóttir ${ }^{\mathrm{e}}$, Mariano Valenza ${ }^{\mathrm{a}}$ \\ a Università di Palermo, DiSTeM, Palermo, Italy \\ ${ }^{\mathrm{b}}$ Istituto Nazionale di Geofisica e Vulcanologia, INGV, Sezione di Palermo, Palermo, Italy \\ c Icelandic Meteorological Office, IMO, Reykjavík, Iceland \\ ${ }^{d}$ British Geological Survey, BGS, Nottingham, UK \\ e Iceland GeoSurvey, ÍSOR, Reykjavík, Iceland
}

\section{A R T I C L E I N F O}

\section{Article history:}

Received 28 July 2015

Received in revised form 13 November 2015

Accepted 21 November 2015

Available online 23 November 2015

\section{Keywords:}

Magmatic gas scrubbing

Gas-water-rock interaction

$\mathrm{EQ} 3 / 6$

Hydrothermal systems

Iceland

\begin{abstract}
A B S T R A C T
Gas-water-rock reactions taking place within volcano-hosted hydrothermal systems scrub reactive, water-soluble species (sulfur, halogens) from the magmatic gas phase, and as such play a major control on the composition of surface gas manifestations. A number of quantitative models of magmatic gas scrubbing have been proposed in the past, but no systematic comparison of model results with observations from natural systems has been carried out, to date. Here, we present the results of novel numerical simulations, in which we initialized models of hydrothermal gaswater-rock at conditions relevant to Icelandic volcanism. We focus on Iceland as an example of a "wet" volcanic region where scrubbing is widespread. Our simulations were performed (using the EQ3/6 software package) at shallow (temperature $<106^{\circ} \mathrm{C}$; low-T model runs) and deep hydrothermal reservoir (200-250 ${ }^{\circ} \mathrm{C}$; high-T model runs) conditions. During the simulations, a high-temperature magmatic gas phase was added stepwise to an initial meteoric water, in the presence of a dissolving aquifer rock. At each step, the chemical compositions of coexisting aqueous solution and gas phase were returned by the model. The model-derived aqueous solutions have compositions that describe the maturation path of hydrothermal fluids, from immature, acidic Mg-rich waters, toward Na-Cl-rich mature hydrothermal brines. The modeled compositions are in fair agreement with measured compositions of natural thermal waters and reservoir fluids from Iceland. We additionally show that the composition of the modelgenerated gases is strongly temperature-dependent, and ranges from $\mathrm{CO}_{2(\mathrm{~g})}$-dominated (for temperatures $\leq 80$ ${ }^{\circ} \mathrm{C}$ ) to $\mathrm{H}_{2} \mathrm{O}_{(\mathrm{g})}$-dominated (and more $\mathrm{H}_{2} \mathrm{~S}_{(\mathrm{g})}$ rich) for temperatures $>100{ }^{\circ} \mathrm{C}$. We find that this range of model gas compositions reproduces well the $\left(\mathrm{H}_{2} \mathrm{O}-\mathrm{CO}_{2}-\mathrm{S}_{\mathrm{TOT}}\right)$ compositional range of reservoir waters and surface gas emissions in Iceland. From this validation of the model in an extreme end-member environment of high scrubbing, we conclude that $\mathrm{EQ} 3 / 6$-based reaction path simulations offer a realistic representation of gas-water-rock interaction processes occurring underneath active magmatic-hydrothermal systems.
\end{abstract}

(c) 2015 Elsevier B.V. All rights reserved.

\section{Introduction}

A recurrent, but sometimes overlooked, control factor on the chemistry of volcanic gas emissions is the interaction between magmatic gases and groundwater/hydrothermal systems. This process, commonly referred as magmatic scrubbing (Symonds et al., 2001), takes place as rising magmatic gases encounter any aquifer interposed between the source magma stored at depth and the surface. The resulting gas-water-rock interactions cause partitioning of water-soluble species ( $\mathrm{S}$, halogens) into aqueous solutions, and irreversibly modify the composition of the primary magmatic gas phase. Quantitative assessment of scrubbing is, therefore, essential for interpreting mechanisms and evolution of volcanichydrothermal unrests (Doukas and Gerlach, 1995; Gerlach et al., 2008;

\footnotetext{
* Corresponding author.

E-mail address: rossella.dinapoli@unipa.it (R. Di Napoli).
}

Ilyinskaya et al., 2015; Symonds et al., 2001, 2003; Werner et al., 2008, 2012; Shinohara et al., 2015). The mechanism of magmatic gas scrubbing by hydrothermal systems was introduced in the fifties (White, 1957), but it was only in the 1990s that scrubbing was invoked as a most important process to explain the anomalous low fluxes of magmatic $\mathrm{SO}_{2}$ and $\mathrm{HCl}$ observed at many volcanoes worldwide, both before and after eruptions (Doukas and Gerlach, 1995; Reed, 1997). Quantitative modeling of magmatic gas scrubbing started with Symonds et al. in 2001. By using the reaction path modeling approach and the CHILLER (Reed, 1982, 1998; Spycher and Reed, 1988) and GASWORKS (Symonds and Reed, 1993) programs, the Authors numerically investigated scrubbing at shallowand deep-water conditions, by simulating the injection of increasing amounts of a magmatic gas $\left(\mathrm{T}=915^{\circ} \mathrm{C}\right.$ ) to aqueous solutions (ranging from diluted meteoric water and to hydrothermal solutions), in the 0.1$5 \mathrm{MPa}$ pressure range. Results of these simulations highlighted the large impact of scrubbing on the chemistry (abundance of $\mathrm{SO}_{2(\mathrm{~g})}, \mathrm{HCl}_{(\mathrm{g})}, \mathrm{HF}_{(\mathrm{g})}$ and, to a minor extent, $\mathrm{CO}_{2(\mathrm{~g})}$ and $\mathrm{H}_{2} \mathrm{~S}_{(\mathrm{g})}$ ) of volcanic gases. Symonds 
et al. (2001) also discussed the implications of scrubbing for volcano monitoring, and concluded that volcanic emissions of $\mathrm{SO}_{2(\mathrm{~g})}$ and $\mathrm{HCl}_{(\mathrm{g})}$ are essentially reduced when scrubbing occurs. In such conditions, $\mathrm{CO}_{2(\mathrm{~g})}$ remains the most useful magmatic gas species to be monitored, until interactions between magmatic gas and hydrothermal aquifers are eluded by opening of a dry degassing pathway to the surface, shortly prior to or during a volcanic eruption. More recently, Marini and Gambardella (2005) first tested the ability of the EQ3/6 software package to model the irreversible gas mass exchanges occurring during addition of magmatic gas to pure water, at near-surface conditions ( $0.1 \mathrm{MPa})$. The obtained results were qualitatively similar to those of Symonds et al. (2001), confirming utility and flexibility of EQ3/6 for scrubbing calculations. More recent applications of EQ3/6 were presented in Di Napoli et al. (2013) and Ilyinskaya et al. (2015).

In spite of the major advance reached in past studies, application of thermodynamics models to scrubbing have not yet been validated using measured (natural) gas compositions. In this paper, we apply the reaction path modeling approach (Helgeson, 1968) with the specific objective of quantitatively investigating magmatic gas scrubbing at two volcanoes exhibiting extensive scrubbing: Hekla volcano and the Krýsuvík volcanic system, both in Iceland ( $\mathrm{Hk}$ and $\mathrm{Kr}$ in Fig. 1). These case studies are here taken as archetypes of systems in which gaswater-rock interactions proceed in shallow and deep-reservoir hydrothermal environments, respectively. So doing, we provide more theoretical and observational confirmation to our initial attempts to model magmatic gas scrubbing at Icelandic volcanoes (Ilyinskaya et al., 2015) and, even more importantly, extend these to higher-temperature hydrothermal interactions. The large mass of previous work on hydrothermal systems has clearly demonstrated that compositions of surface hydrothermal manifestations are controlled by a variety of processes, occurring at both deep reservoir conditions (e.g., fluid-mineral reactions; Arnórsson et al., 1983; Giggenbach, 1981, 1988; Reed and Spycher, 1984; Stefánsson and Arnórsson, 2000, 2002) and upon ascent of fluids from the reservoir to surface (e.g., boiling, degassing, mixing, oxidation and further water-rock interactions; Arnórsson, 1985; Arnórsson et al., 2007; Fournier, 1989; Kaasalainen and Stefánsson, 2012; Markússon and Stefánsson, 2011; Nordstrom et al., 2009). In comparison to these well characterised processes, the interaction mechanisms (scrubbing) of magmatic volatiles inside hydrothermal reservoirs have received less attention so far, and motivate the present study. We ultimately demonstrate that EQ3/6 scrubbing models satisfactorily reproduce the chemical compositions of cold (Hekla-type) natural gas emissions and, when combined with other processes such as boiling, of the near-boiling hydrothermal steam vents in Iceland. We also find good match between our model fluids and compositions of reservoir fluids in boreholes. Our developed model approach, after the validation study described here, can now generically be used to investigate scrubbing process at any volcano worldwide.

\section{Materials and methods}

\subsection{EQ3/6 code}

Reaction path models of magmatic gas scrubbing are here carried out by means of EQ3/6 (version 7.0; Daveler and Wolery, 1992; Wolery, 1979, 1992a,b; Wolery and Daveler, 1992), a software package combining together the EQ3NR and EQ6 codes (see Appendices A and B). By using thermodynamic and kinetic constraints, this software performs

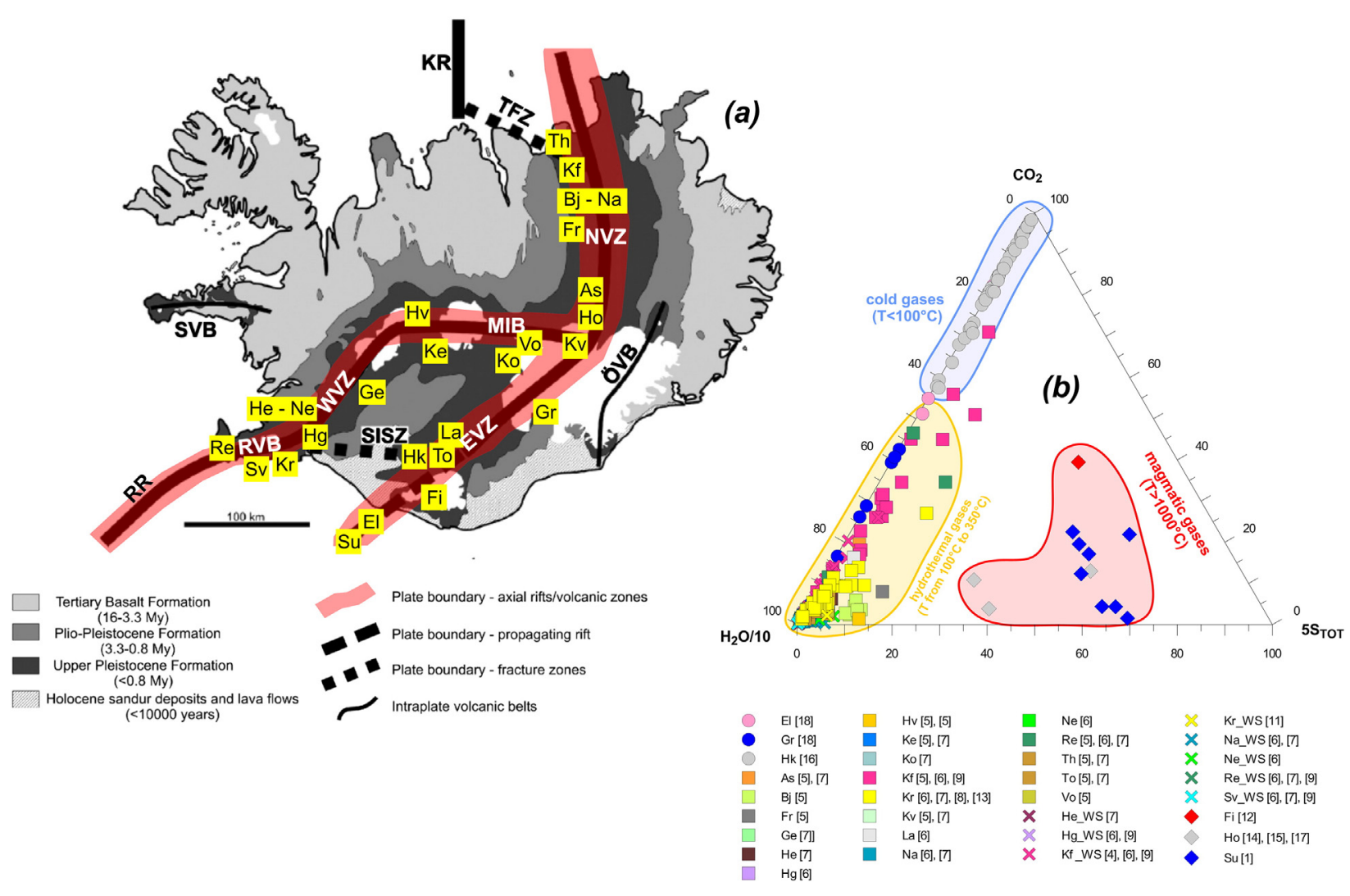

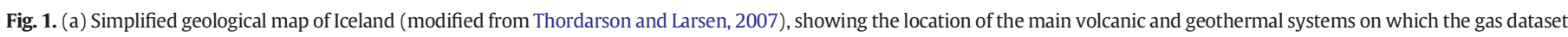

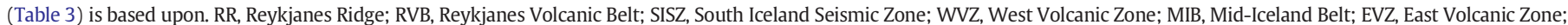

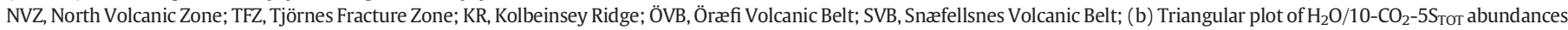

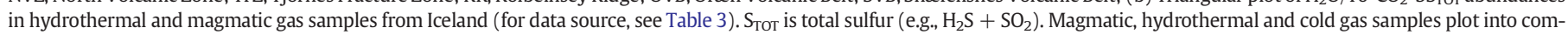
positionally distinct domains (see text for discussion). 
numerical simulations of aqueous solutions that evolve, through a set of irreversible (not at equilibrium) reactions, towards a final equilibrium state. The reaction progress variable $(\xi)$ (Helgeson, 1968) describes the extent to which reactions have progressed.

\subsection{Range of conditions investigated by EQ3/6 reaction path modeling}

Scrubbing of a high-temperature magmatic gas at hydrothermal or shallow groundwater conditions is simulated by EQ3/6 via the stepwise addition of a deep magmatic gas (initial gas) to $1 \mathrm{~kg}$ of a starting aqueous solution, in contact with reservoir rocks (solid reactants) (Table 1 and Fig. 2). The initialization of the model runs is described in Appendices A and B. The model input parameters are listed in Tables 1-2 and A.1.

We investigated scrubbing at temperatures of $\leq 106^{\circ} \mathrm{C}$ (low-T model runs; Table 2) and $200-250{ }^{\circ} \mathrm{C}$ (high-T model runs; Table 2 ), in the attempt to compare our modelling results with natural gas compositions from respectively low-T (e.g., Hekla volcano) and higher-T (e.g., Krýsuvík) volcanic/hydrothermal systems. The low-T model runs are an extension-implementation of those presented in Ilyinskaya et al. (2015): a wider range of gas/water ratios is explored and, more importantly, $\mathrm{HCl}_{(\mathrm{g})}$ is now incorporated in the model. The high-T runs are first presented in this study.

A total of 8 different model run types $(\mathrm{A}-\mathrm{H})$ were performed (Table 2). Low-T run types (A to D in Table 2) consisted each of 5 to 11 runs (e.g., A_1, A_2, etc.), which corresponded to distinct steps (0.6-1.5 mol each) of gas addition to a starting aqueous solution (see Section 4 and Fig. 2). Similarly, seven runs (e.g., seven iterative additions of $0.3 \mathrm{~mol}$ gas each) were performed in each of the high-T run types ( $\mathrm{E}$ to $\mathrm{H}$; Table 2).

\subsection{Degassing calculations}

EQ3/6 code does not implement any routine to perform degassing calculations. We therefore used an independent calculation routine to (i) extract from EQ6 the model aqueous solutions, (ii) calculate for each of them the total gas pressure Pgas ${ }_{\mathrm{TO}}$ (where Pgas Pgot $_{\mathrm{TO}}=$ $\mathrm{P}_{\mathrm{H} 2 \mathrm{O}}+\mathrm{P}_{\mathrm{CO} 2}+\mathrm{P}_{\mathrm{H} 2 \mathrm{~S}}+\ldots$ ) (Fig. 5), and (iii) process any gas oversaturated solution (where Pgas $_{\mathrm{TO}}>\mathrm{P}_{\mathrm{run}}$ ) in a single-step degassing process (Henley et al., 1984), to release the excess dissolved gas until attainment of an equilibrium condition (Pgas PoT $_{\text {To }}=\mathrm{P}_{\text {run }}$ ) (Fig. 2 and Table 2). In brief, from the molar fractions of each $\mathrm{j}$-th gas species in the un-degassed aqueous solution $\left(\left(n_{j} / n_{\mathrm{H} 2 \mathrm{O}}\right)_{i}\right)$ (aqueous solution_n in Fig. 2), extracted from the EQ6 output file, we calculated the gas molar fractions in the degassed aqueous solution_n $\left(\left(n_{j} / n_{\mathrm{H} 2 \mathrm{O}}\right)_{l q}\right)$ and in the separated gas phase_n $\left(\left(n_{j} / n_{\mathrm{H} 2 \mathrm{O}}\right)_{\mathrm{g}}\right)$ (see Fig. 2$)$, using Eqs. (1)-(2):

$$
\left(\frac{n_{j}}{n_{\mathrm{H}_{2} \mathrm{O}}}\right)_{l q}=\left(\frac{n_{j}}{n_{\mathrm{H}_{2} \mathrm{O}}}\right)_{i} \cdot\left(\frac{1}{B_{j} \cdot f+1-f}\right)
$$

$\left(\frac{n_{j}}{n_{\mathrm{H}_{2} \mathrm{O}}}\right)_{\mathrm{g}}=\left[\left(\frac{n_{j}}{n_{\mathrm{H}_{2} \mathrm{O}}}\right)_{i}-\left(\frac{n_{j}}{n_{\mathrm{H}_{2} \mathrm{O}}}\right)_{\mathrm{lq}} \cdot(1-f)\right] \div f$

where $f$ is the degassing fraction, and $\left(B_{j}\right)$ the partition coefficient of each gas, calculated at the run temperature $\left(T_{\text {run }}\right)$ using the relations of Giggenbach (1980). The value of $f$ was interactively changed until Eq. (3) was satisfied:

$P_{\text {gas }}=\sum_{j \text { Tо }}\left(\frac{n_{j}}{n_{\mathrm{H}_{2} \mathrm{O}}}\right)_{\text {lq }} \cdot K_{\mathrm{Hj}}=P_{\text {run }}\left(\right.$ at $\left.T_{\text {run }}\right)$

where $P_{\text {gas TOT }}$ is total pressure (as sum of partial pressure values of all $\mathrm{j}$ th gas species) of degassed aqueous solution, $\left(n_{j} / n_{\mathrm{H} 2 \mathrm{O}}\right)_{l q}$ (derived from Eq. (1)) and $K_{H j}$ are the molar fractions and the Henry's constant of jth gas specie in degassed aqueous solution, respectively, and $P_{\text {run }}$ is the run pressure. $P_{\text {run }}$ was taken constant at 1.013 bar for $\mathrm{T}<100{ }^{\circ} \mathrm{C}$ runs, and equaled the water saturation pressure at the simulation-run temperature $\left(T_{\text {run }}\right)$ in high-T $\left(200-250^{\circ} \mathrm{C}\right)$ runs (Table 2$)$.

\section{Background}

\subsection{Hekla and krýsuvík}

Hekla (Fig. 1) is one of the most active and frequently erupting volcanoes in Iceland (Höskuldsson et al., 2007; Larsen et al., 1999), but the compositional signature of its magmatic gases, its magmatic gas output, and the structure of its magmatic-hydrothermal system, all remain very poorly known. This paucity of information reflects the absence of sustained gas vent emissions during quiescent intervals; consequently, degassing at Hekla has long been only indirectly investigated through analysis of groundwaters issuing at the base of the volcano (Flaathen and Gíslason, 2007; Flaathen et al., 2009; Gíslason et al., 1992). Warm $\left(40-70{ }^{\circ} \mathrm{C}\right.$ ), diffuse degassing on the volcano's summit emits $\sim 14$ tons of $\mathrm{CO}_{2}$-dominated volcanic gas/day (Ilyinskaya et al., 2015). The Authors identified a magmatic origin for this gas based on $\mathrm{C}$ isotopes, and preliminary reaction path modeling suggested that these $\mathrm{CO}_{2}$-rich $(\mathrm{S}$ poor) fluids may be the result of extensive scrubbing of deeply sourced magmatic volatiles into the Hekla groundwater system.

Table 1

Chemical composition of the aqueous solution and reactants (gas and solids) used to initialized the reaction path modeling here presented.

\begin{tabular}{|c|c|c|c|c|c|c|c|c|}
\hline \multirow{2}{*}{\multicolumn{2}{|c|}{$\frac{\text { Aqueous solution }}{\text { Sample RB1E }}$}} & & \multicolumn{2}{|c|}{ Gas reactant } & \multicolumn{4}{|c|}{ Solid reactants } \\
\hline & & & $\begin{array}{l}\text { Fimmvördu } \\
\text { Eyjafjallajö }\end{array}$ & $\begin{array}{l}\text { fissural eruption from } \\
\text { golcano (1) }\end{array}$ & \multicolumn{2}{|c|}{ Basaltic andesitic glass ( 3 ) } & \multicolumn{2}{|c|}{ Basaltic glass (3) } \\
\hline \multicolumn{3}{|c|}{ Initial aqueous solution } & \multicolumn{2}{|l|}{ Initial gas } & \multicolumn{2}{|c|}{ Hyd-Hekla-glass (solid reactants) } & \multicolumn{2}{|c|}{ Hyd-Krýsuvík-glass (solid reactants) } \\
\hline $\mathrm{T}_{w}$ & 4.1 & ${ }^{\circ} \mathrm{C}$ & $\mathrm{T}_{g}$ & $800^{\circ} \mathrm{C}$ & \multicolumn{2}{|c|}{$\mathrm{SiAl}_{0.31} \mathrm{O}_{2}(\mathrm{OH})_{0.93}$} & \multicolumn{2}{|c|}{$\mathrm{SiAl}_{0.32} \mathrm{O}_{2}(\mathrm{OH})_{0.96}$} \\
\hline Eh & 0.8 & Volt & $\mathrm{H}_{2} \mathrm{O}$ & $81.49 \%$ in vol. & & & & \\
\hline $\mathrm{pH}$ & 7.7 & & $\mathrm{CO}_{2}$ & $15.28 \%$ in vol. & \multicolumn{2}{|c|}{ Hekla-glass-cations (special reactant) ${ }^{(*)}$} & \multicolumn{2}{|c|}{ Hyd-Krýsuvík-glass (special reactant) ${ }^{(*)}$} \\
\hline $\mathrm{SiO}_{2}$ & 21.71 & $\mathrm{mg} / \mathrm{l}$ & $\mathrm{SO}_{2}$ & $3.06 \%$ in vol. & $\mathrm{Fe}$ & $0.174 \mathrm{~mol}$ & Fe & $0.240 \mathrm{~mol}$ \\
\hline $\mathrm{Na}^{+}$ & 42.14 & $\mathrm{mg} / \mathrm{l}$ & $\mathrm{HCl}$ & $0.18 \%$ in vol. & $\mathrm{Mg}$ & $0.076 \mathrm{~mol}$ & $\mathrm{Mg}$ & $0.170 \mathrm{~mol}$ \\
\hline $\mathrm{Ca}^{2+}$ & 18.99 & $\mathrm{mg} / \mathrm{l}$ & & & $\mathrm{Ca}$ & $0.130 \mathrm{~mol}$ & $\mathrm{Ca}$ & $0.220 \mathrm{~mol}$ \\
\hline $\mathrm{K}^{+}$ & 2 & $\mathrm{mg} / \mathrm{l}$ & & & $\mathrm{Na}$ & $0.142 \mathrm{~mol}$ & $\mathrm{Na}$ & $0.090 \mathrm{~mol}$ \\
\hline $\mathrm{Mg}^{2+}$ & 17.395 & $\mathrm{mg} / \mathrm{l}$ & & & $\mathrm{K}$ & $0.030 \mathrm{~mol}$ & $\mathrm{~K}$ & $0.008 \mathrm{~mol}$ \\
\hline $\mathrm{HCO}_{3}^{-}$ & $3.20 \cdot 10^{-3}$ & $\mathrm{~mol} / \mathrm{kg}$ & & & 0 & $0.029 \mathrm{~mol}$ & 0 & $0.223 \mathrm{~mol}$ \\
\hline $\mathrm{Cl}^{-}$ & 9.75 & $\mathrm{mg} / \mathrm{l}$ & & & & & & \\
\hline $\mathrm{NO}_{3}^{-}$(as $\left.\mathrm{NH}_{3} \mathrm{aq}\right)$ & $3.22 \cdot 10^{-6}$ & $\mathrm{~mol} / \mathrm{kg}$ & & & & & & \\
\hline $\mathrm{SO}_{4}^{2-}$ & 22.8 & $\mathrm{mg} / \mathrm{l}$ & & & & & & \\
\hline $\mathrm{Al}^{3+}$ & 0.016 & $\mathrm{mg} / \mathrm{l}$ & & & & & & \\
\hline $\mathrm{Fe}^{2+}$ & 0.015 & $\mathrm{mg} / \mathrm{l}$ & & & & & & \\
\hline
\end{tabular}

(1) Burton et al. (2010); (2) Holm et al. (2010); (3) Wolff-Boenisch et al. (2004); ${ }^{(*)}$ special reactant chemical composition (see Appendix A for details). 

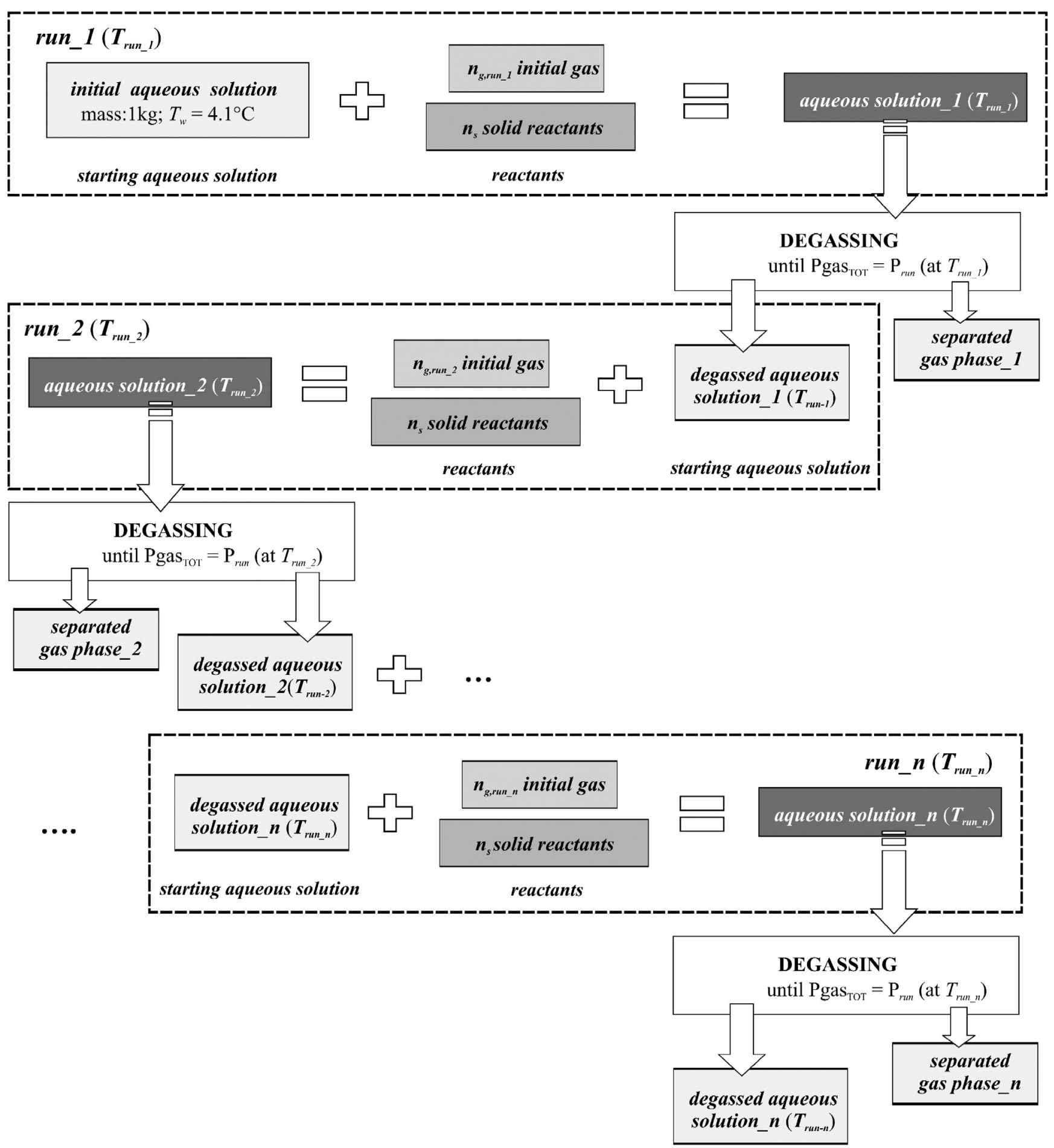

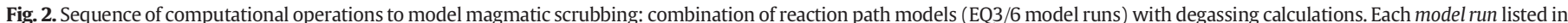

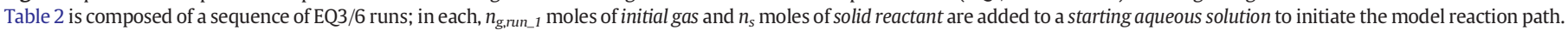

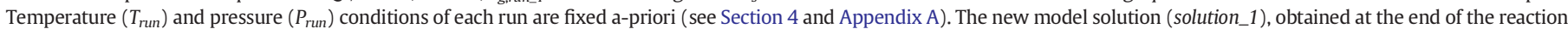

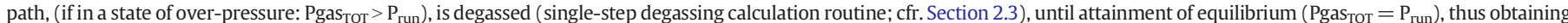

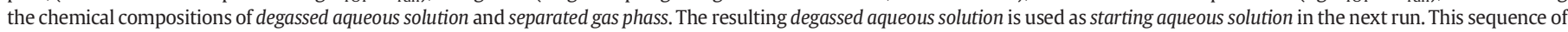
EQ3/6 run simulations and degassing calculations are iteratively repeated (see Appendix A).

The Krýsuvík geothermal area (Arnórsson, 1987), in the Reykjanes Peninsula (Fig. 1a), is the surface expression of one of the several active hydrothermal systems in Iceland (Arnórsson, 1995). Thermal manifestations include steam-heated hot springs and mud pools, extensive acid surface alteration, and steaming hot grounds (Markússon and Stefánsson, 2011). In the geothermal reservoir, being $<1000$ m deep (Arnórsson et al., 1975) and $200-300{ }^{\circ} \mathrm{C}$ in temperature (Arnórsson,
1987; Arnórsson and Gunnlaugsson, 1985; Poreda et al., 1992), the recharge meteoric fluids (with some minimal seawater contributions) react with host rock minerals in the presence of a deeply sourced (possibly magmatic) gas phase, acquiring the characteristic $\mathrm{NaCl}-$ composition of fully equilibrated hydrothermal brines (Arnórsson et al. 2007; Giggenbach, 1988). Upon depressurization along faults and fractures, these reservoir fluids boil to produce the geothermal 
Table 2

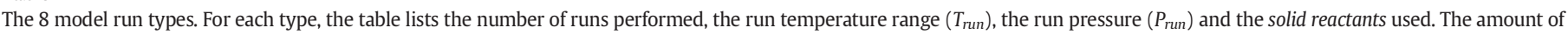

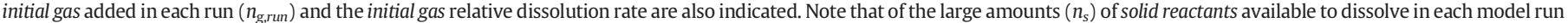
type (from $77.26 \mathrm{~mol}$ to $289.23 \mathrm{~mol}$ ), only a small fraction is actually consumed in the runs (listed in the column "consumed"). See Text and Appendix A for details.

\begin{tabular}{|c|c|c|c|c|c|c|c|c|c|}
\hline \multirow[t]{2}{*}{$\begin{array}{l}\text { Model } \\
\text { run ID }\end{array}$} & \multirow[t]{2}{*}{$\begin{array}{l}\text { Number } \\
\text { of runs }\end{array}$} & \multirow{2}{*}{$\frac{\text { Model run }}{\mathrm{T}_{\text {run }}\left({ }^{\circ} \mathrm{C}\right)}$} & \multirow{2}{*}{$\frac{\text { Model run }}{\mathrm{P}_{\text {run }} \text { (bar) }}$} & \multirow{2}{*}{$\begin{array}{l}\text { Initial gas } \\
\frac{\left(n_{\text {g,TOT }} ; \mathrm{mol}\right)}{}\end{array}$} & \multirow[t]{2}{*}{$\begin{array}{l}\text { Initial gas added per run } \\
\left(n_{\text {g,run }} ; \mathrm{mol}\right)\end{array}$} & \multirow[t]{2}{*}{$\begin{array}{l}\text { Initial gas relative } \\
\text { dissolution rate }{ }^{(*)}\end{array}$} & \multirow[t]{2}{*}{ Solid reactant type } & \multirow{2}{*}{$\begin{array}{l}\begin{array}{l}\text { Solid } \\
\text { reactant }\end{array} \\
\frac{\left(n_{s} ; \mathrm{mol}\right)}{}\end{array}$} & \multirow{2}{*}{$\begin{array}{l}\text { Solid reactant } \\
\text { "consumed" at } \\
\text { each run (mol) }\end{array}$} \\
\hline & & & & & & & & & \\
\hline \multicolumn{10}{|c|}{ Low temperature model runs } \\
\hline A_1-11 & 11 & 14-106 & 1.013 & 6.6 & 0.6 & 1 & None & None & None \\
\hline \multirow[t]{2}{*}{ B_1-5 } & 5 & 14-106 & 1.013 & 6.6 & ( 0.6 at the first run) 1.5 & 25.45 & Hyd_Hekla_Glass (1) & 77.26 & $0.022-0.059$ \\
\hline & & & & & & & Hekla-glass-cations (1) & 77.26 & $0.022-0.059$ \\
\hline \multirow[t]{2}{*}{ C_1-5 } & 5 & 14-106 & 1.013 & 6.6 & (0.6 at the first run) 1.5 & 25.50 & Hyd_Hekla_Glass (1) & 77.26 & $0.022-0.059$ \\
\hline & & & & & & & Hekla-glass-cations (1) & 77.26 & $0.022-0.059$ \\
\hline \multirow[t]{2}{*}{ D_1-5 } & 5 & $14-106$ & 1.013 & 6.6 & (0.6 at the first run) 1.5 & 26.00 & Hyd_Hekla_Glass (1) & 77.26 & $0.022-0.059$ \\
\hline & & & & & & & Hekla-glass-cations (1) & 77.26 & $0.022-0.059$ \\
\hline \multicolumn{10}{|c|}{ High temperature model runs } \\
\hline \multirow[t]{2}{*}{ E_1-7 } & 7 & 200 & 15.537 & 2 & ( 0.1 at the first run) 0.3 & 17 & Hyd_Krýsuvík_Glass (1) & 289.23 & $0.19-2.85$ \\
\hline & & & & & & & Krýsuvík-glass-cations (1) & 289.23 & $0.19-2.85$ \\
\hline \multirow[t]{2}{*}{ F_1-7 } & 7 & 200 & 15.537 & 2 & (0.1 at the first run) 0.3 & 100 & Hyd_Krýsuvík_Glass (1) & 289.23 & $0.19-2.85$ \\
\hline & & & & & & & Krýsuvík-glass-cations (1) & 289.23 & $0.19-2.85$ \\
\hline \multirow[t]{2}{*}{ G_1-7 } & 7 & 250 & 39.737 & 2 & (0.1 at the first run) 0.3 & 17 & Hyd_Krýsuvík_Glass (1) & 289.23 & $0.17-0.35$ \\
\hline & & & & & & & Krýsuvík-glass-cations (1) & 289.23 & $0.17-0.35$ \\
\hline \multirow[t]{2}{*}{ H_1-7 } & 7 & 250 & 39.737 & 2 & ( 0.1 at the first run) 0.3 & 100 & Hyd_Krýsuvík_Glass (1) & 289.23 & $0.17-0.35$ \\
\hline & & & & & & & Krýsuvík-glass-cations (1) & 289.23 & $0.17-0.35$ \\
\hline
\end{tabular}

(1) Wolff-Boenisch et al. (2004); ${ }^{(*)}$ normalised to the solid reactant reaction rate (see text and Appendix A for detail).

steams feeding the surface $\left(\sim 100{ }^{\circ} \mathrm{C}\right)$ fumaroles (Arnórsson, 1995; Guðjónsdóttir, 2014; Poreda et al., 1992). These rising steams, upon shallow condensation, and oxidation of $\mathrm{H}_{2} \mathrm{~S}$ to $\mathrm{H}_{2} \mathrm{SO}_{4}$, lead to intensive acidic alteration and to formation of $\mathrm{SO}_{4}$-rich steam-heated springs and pools (Markússon and Stefánsson, 2011).

\subsection{The natural gas dataset}

Iceland is an ideal location to study gas-water-rock interactions because of widespread volcanic and geothermal activity in the presence of huge groundwater circulation. We use this end-member environment to validate the use of our EQ3/6 models for simulating magmatic gas scrubbing at natural conditions. Although our models were specifically initialised (Tables 1-2) at conditions suitable for Hekla volcano and the Krýsuvík geothermal system, that are respectively examples of gaswater-rock reactions at shallow $\left(<100{ }^{\circ} \mathrm{C}\right)$ and deep-reservoir $(200-250$ ${ }^{\circ} \mathrm{C}$ ) conditions, we extend our model vs. natural sample comparison to volcanic gases released from the 26 active volcano/hydrothermal systems in Iceland (Fig. 1b and Table 3).

The complex interactions between the Mid-Atlantic Ridge and an underlying mantle plume have controlled the location of volcanism in Iceland (Fig. 1a): due to the westward American-Eurasian plate boundary migration, relative to the stable Icelandic hotspot, volcanic activity has progressively migrated eastward (Garcia et al., 2003; Ward and Björnsson, 1971; Sæmundsson, 1974), from the West Volcanic Zones (>3 Myr; Garcia et al., 2003) towards the today active rifts of the North and the East Volcanic Zones, hosting the currently most active volcanic systems (Fig. 1a). The volcanic gases in our dataset (Table 3) include samples from both West and East-North Icelandic Volcanic Zones (Fig. 1a). Their isotopic features (Arnórsson, 1986; Arnórsson and Barnes, 1983), with their magmatic $\delta^{13} \mathrm{C}_{(\mathrm{CO})}$ of $\sim-2.5$ to $-4 \%$ 。 (Barry et al., 2014; Marty et al., 1991; Poreda et al., 1992), and the ${ }^{3} \mathrm{He} /{ }^{4} \mathrm{He}$ isotopic ratios higher than MORB (from 8.5 to $20 \mathrm{Ra}$; Poreda et al., 1992), reflect well the strong deep-mantle plume imprint.

The natural gas compositions listed in Table 3 are based upon a review of published, data of hydrothermal fumaroles and near-vent plumes in Iceland. This compilation has been extended with the results of new unpublished gas measurements (El, Gr in Table 3), obtained during field campaigns made for volcano monitoring at the Icelandic Meteorological Office within the context of the EU-FP7 project "Futurevolc" with a portable Multi-component Gas Analyzer System (Multi-GAS; Aiuppa et al., 2005). We additionally list in Table 3 the compositions of well fluids (well steam, "WS", and dissolved gases in reservoir waters, "WW") collected from geothermal boreholes at depth (data source: Ármannsson et al. 1982; Arnórsson, 1986; Arnórsson and Gunnlaugsson, 1985; Arnórsson et al., 1975; Bjarnason, 2000; Guðmundsson et al., 1975). These borehole data provide constraints on reservoir fluid composition, prior to decompression boiling, and are therefore very useful independent tests for the validity of our model outputs.

In the $\mathrm{H}_{2} \mathrm{O} / 10-\mathrm{CO}_{2}-5 \mathrm{~S}_{\mathrm{TOT}}$ triangular plot of Fig. $1 \mathrm{~b}$, the natural gas samples (Table 3 ) fall into three distinct compositional domains. The majority of the samples are the near-to-boiling steam vents/fumaroles, corresponding to the surface discharges of high-temperature $\left(\mathrm{T}>180^{\circ} \mathrm{C}\right)$, volcano-hosted hydrothermal reservoirs. These samples are identified as "hydrothermal gases" in Fig. 1b. Although a magmatic origin (from a MORB-mantle plume mixture) is implicated for both $\mathrm{CO}_{2}$ and noble gases, based on isotopic data (Barry et al., 2014; Ilyinskaya et al., 2015; Kurz et al., 1985; Macpherson et al., 2005; Polak et al., 1976; Poreda et al., 1980, 1986, 1992), these gas samples show clear signs of hydrothermal derivation of the emitted fluids, including (Fig. 1b): ( $i$ ) very high $\mathrm{H}_{2} \mathrm{O} / \mathrm{CO}_{2}$ ratios (often $>100$ and up to 630 ), (ii) very low total sulfur contents ( $\mathrm{S}_{\mathrm{TOT}}<0.3 \% \mathrm{vol} ; \mathrm{CO}_{2} / \mathrm{S}_{\text {TOT }} 1.9-61,450$ ), and (iii) dominance of $\mathrm{H}_{2} \mathrm{~S}$ over $\mathrm{SO}_{2}$ (typically below detection). Data from the Krýsuvík geothermal system (Arnórsson, 1986, 1987; Arnórsson and Gunnlaugsson, 1985; Guðjónsdóttir, 2014) clearly fall into this category of $\mathrm{H}_{2} \mathrm{O}$-rich hydrothermal steam samples (Fig. 1b). These compositions overall imply that vigorous interaction (re-equilibration) of magmatic fluids within hydrothermal reservoirs must have occurred (Arnórsson, 1983, 1986; Arnórsson and Gunnlaugsson, 1985; Barth, 1950; Sigvaldason, 1966). The very low sulfur concentrations, in particular, reflect extensive magmatic gas scrubbing at hydrothermal reservoir conditions (Arnórsson, 1986; Arnórsson and Barnes, 1983; Arnórsson and Gunnlaugsson, 1985; Ilyinskaya et al., 2015; Oskarsson, 1984). Deep-reservoir well fluids (WW and WS in Table 3), collected from geothermal boreholes at depth, also share similar $\mathrm{H}_{2} \mathrm{O}$-rich and S-poor compositions (Arnórsson and Gunnlaugsson, 1985).

A second group of "cold gases" (Fig. 1b) essentially correspond to gas samples from Hekla volcano; these exhibit unusually $\mathrm{CO}_{2}$-rich compositions $\left(\mathrm{H}_{2} \mathrm{O} / \mathrm{CO}_{2}\right.$ of $\left.1.2 \pm 1.4\right)$, that have been interpreted (Ilyinskaya et al. 2015) as reflecting even larger extents of magmatic gas scrubbing, occurring in a lower-temperature $\left(<100^{\circ} \mathrm{C}\right)$ groundwater environment.

Finally, "magmatic gases" are characterized by much higher $\mathrm{S}_{\mathrm{TOT}}$ (>3\% vol.), lower $\mathrm{CO}_{2} / \mathrm{S}_{\mathrm{TOT}}$ (from 1.1 to 5 ) and $\mathrm{H}_{2} \mathrm{O} / \mathrm{CO}_{2}$ (as low as 5; 
Table 3

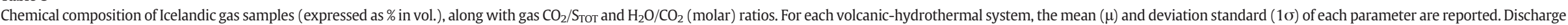

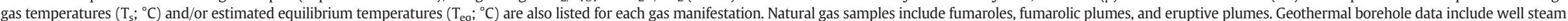

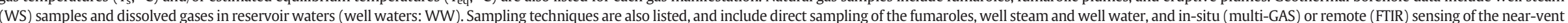
plumes.

\begin{tabular}{|c|c|c|c|c|c|c|c|c|c|c|c|c|}
\hline Site & $\begin{array}{l}\text { Abbreviation } \\
\text { and references }\end{array}$ & Type & $\begin{array}{l}\text { Measurement } \\
\text { technique }\end{array}$ & $\mathrm{H}_{2} \mathrm{O} \mu \pm 1 \sigma$ & $\mathrm{CO}_{2} \mu \pm 1 \sigma$ & $\mathrm{H}_{2} \mathrm{~S} \mu \pm 1 \sigma$ & $\mathrm{SO}_{2} \mu \pm 1 \sigma$ & $\mathrm{HCl} \mu \pm 1 \sigma$ & $\begin{array}{l}\mathrm{CO}_{2} / \mathrm{S}_{\mathrm{TOT}} \\
\mu \pm 1 \sigma\end{array}$ & $\begin{array}{l}\mathrm{H}_{2} \mathrm{O} / \mathrm{CO}_{2} \\
\mu \pm 1 \sigma\end{array}$ & $\mathrm{T}_{\mathrm{s}}$ & $\begin{array}{l}\mathrm{T}_{\mathrm{eq}} \\
\mathrm{min}-\mathrm{max}\end{array}$ \\
\hline Askja & As [5], [7] & Fumarole & Direct sampling & $98.9 \pm 1$ & $0.9 \pm 0.1$ & $3.7 \cdot 10^{-2} \pm 3 \cdot 10^{-2}$ & & & $22.8 \pm 8$ & $235 \pm 127$ & 95 & \\
\hline Bjarnarflag & $\mathrm{Bj}[5]$ & Fumarole & Direct sampling & $99.1 \pm 0.6$ & $0.4 \pm 0.2$ & $2.1 \cdot 10^{-1} \pm 6 \cdot 10^{-2}$ & & & $1.9 \pm 1$ & $348 \pm 248$ & 95 & \\
\hline Eldfell & El [18] & Fumarolic plume & MultiGAS & $79.4 \pm 11.9$ & $20.6 \pm 11.9$ & $1.3 \cdot 10^{-2} \pm 1.1 \cdot 10^{-2}$ & & & $2603 \pm 1977$ & $5.5 \pm 3.8$ & 257 & 270 \\
\hline $\begin{array}{l}\text { Eyjafjallajökull/ } \\
\text { Fimmvörduháls }\end{array}$ & $\mathrm{Fi}[12]$ & Plume & FTIR & 81.5 & 15.3 & & 3.06 & 0.17 & 5 & 5.3 & 1125 & \\
\hline Fremrinamur & $\operatorname{Fr}[5]$ & Fumarole & Direct sampling & 92.9 & 1 & $3.3 \cdot 10^{-1}$ & & & 2.9 & 97.5 & 95 & \\
\hline Geysir & $\mathrm{Ge}[7]$ & Fumarole & Direct sampling & 99.6 & 0.2 & $7.6 \cdot 10^{-4}$ & & & 209 & 627 & 95 & \\
\hline Grimsfjall & Gr [18] & Fumarolic plume & MultiGAS & $83.9 \pm 26.4$ & $16.1 \pm 26.4$ & $6.1 \cdot 10^{-3} \pm 2.2 \cdot 10^{-3}$ & & & $5197 \pm 6812$ & $11.6 \pm 43.4$ & 94 & \\
\hline Hekla & $\mathrm{Hk}[16]$ & Fumarolic plume & MultiGAS & 35.6 & $64.4 \pm 27.8$ & $8.2 \cdot 10^{-3} \pm 1.7 \cdot 10^{-2}$ & & & $61,451 \pm 78,690$ & $1.23 \pm 1.4$ & 33.2 & \\
\hline Hengill_WS & He_WS [7] & Well steam & Direct sampling & 99.9 & 0.05 & $2.8 \cdot 10^{-2} \pm 2.7 \cdot 10^{-2}$ & & & $4.2 \pm 3$ & $8345 \pm 7171$ & 253 & $215-290$ \\
\hline Hengill & $\mathrm{He}[7]$ & Fumarole & Direct sampling & 99.1 & 0.7 & $9.1 \cdot 10^{-2}$ & & & 7.6 & 143 & 95 & \\
\hline Holuhraun & Но [14], [15], [17] & Plume & FTIR - MultiGAS & $96 \pm 2.2$ & $2.1 \pm 1.3$ & $1.9 \pm 1$ & 0.03 & & $1.13 \pm 0.49$ & $75.8 \pm 53.7$ & 1125 & \\
\hline Hveragerdi_WW & Hg_WW [6] & Well waters & Direct sampling & 100 & 0.01 & $8.2 \cdot 10^{-4} \pm 4 \cdot 10^{-4}$ & & & $6.1 \pm 1$ & $27,770 \pm 15,452$ & 201 & $182-230$ \\
\hline Hveragerdi_WS & Hg_WS [6], [9] & Well steam & Direct sampling & 99.9 & 0.06 & $7.1 \cdot 10^{-3} \pm 1.8 \cdot 10^{-3}$ & & & $8.9 \pm 5$ & $2140 \pm 1003$ & 204 & $182-230$ \\
\hline Hveragerdi & $\mathrm{Hg}[6]$ & Fumarole & Direct sampling & $99.8 \pm 0.1$ & $0.19 \pm 0.1$ & $7.6 \cdot 10^{-3} \pm 4 \cdot 10^{-3}$ & & & $34.4 \pm 30$ & $600 \pm 222$ & 95 & $182-230$ \\
\hline Hveravellir & $\operatorname{Hv}[5],[6]$ & Fumarole & Direct sampling & $99.3 \pm 0.9$ & 0.11 & $9.6 \cdot 10^{-2} \pm 1.1 \cdot 10^{-1}$ & & & $18.3 \pm 13$ & $950 \pm 250$ & 95 & \\
\hline Kerlingarfjöll & Ke [5], [7] & Fumarole & Direct sampling & $99.4 \pm 0.1$ & $0.38 \pm 0.1$ & $6.6 \cdot 10^{-2} \pm 3 \cdot 10^{-2}$ & & & $6.8 \pm 3$ & $274 \pm 56$ & 95 & \\
\hline Köldukvíslarbotnar & Ко [7] & Fumarole & Direct sampling & 99.5 & 0.4 & $1.8 \cdot 10^{-2}$ & & & 23.8 & 235 & 95 & \\
\hline Krafla_WW & Kf_WW [4], [6], [7], [9] & Well waters & Direct sampling & $99.2 \pm 1$ & $0.7 \pm 0.8$ & $2.1 \cdot 10^{-2} \pm 2.3 \cdot 10^{-2}$ & & & $48.2 \pm 52$ & $2143 \pm 6541$ & 288 & $190-340$ \\
\hline Krafla_WS & Kf_WS [4], [6], [9] & Well steam & Direct sampling & $99.1 \pm 1$ & $0.8 \pm 0.9$ & $2.3 \cdot 10^{-2} \pm 2.8 \cdot 10^{-2}$ & & & $47.9 \pm 46$ & $1179 \pm 2546$ & 326 & $190-340$ \\
\hline Krafla & $\operatorname{Kf}[5],[6]$ & Fumarole & Direct sampling & $91.9 \pm 6.8$ & $6 \pm 5.2$ & $1.4 \cdot 10^{-1} \pm 1 \cdot 10^{-1}$ & & & $58.9 \pm 42$ & $29 \pm 26$ & 95 & \\
\hline Krýsuvík_WW & $\mathrm{Kr}_{-} \mathrm{WW}[2],[3],[9]$ & Well waters & Direct sampling & 100 & $3 \cdot 10-3$ & $1.9 \cdot 10^{-4}$ & & & $65.1 \pm 80$ & $38,084 \pm 7505$ & 157 & 267 \\
\hline Krýsuvik_WS & Kr_WS [11] & Well steam & Direct sampling & 99.7 & 0.2 & $1.9 \cdot 10^{-4} \pm 1.9 \cdot 10^{-4}$ & & & 2.1 & 421 & & \\
\hline Krýsuvík & $\operatorname{Kr}[6],[7],[8],[13]$ & Fumarole & $\begin{array}{l}\text { Direct sampling - } \\
\text { MultiGAS }\end{array}$ & $99.2 \pm 0.7$ & $0.7 \pm 0.6$ & $6.5 \cdot 10^{-2} \pm 7 \cdot 10^{-2}$ & & & $17.3 \pm 17$ & $224 \pm 97$ & 95 & \\
\hline Kverkfjöll & $\operatorname{Kv}[5],[7]$ & Fumarole & Direct sampling & $99.2 \pm 0.3$ & $0.5 \pm 0.1$ & $4.5 \cdot 10^{-2} \pm 1 \cdot 10^{-2}$ & & & $10.8 \pm 2$ & $222 \pm 55$ & 95 & \\
\hline Landmannalaugar & La [6] & Fumarole & Direct sampling & $99.6 \pm 0.5$ & $0.3 \pm 0.5$ & $2.2 \cdot 10^{-2} \pm 2.8 \cdot 10^{-2}$ & & & $15.7 \pm 7$ & $628 \pm 343$ & 95 & \\
\hline Námafjall_WW & Na_WW [6] & Well waters & Direct sampling & 99.9 & 0.05 & $3.5 \cdot 10^{-2} \pm 1.9 \cdot 10^{-2}$ & & & 1.5 & $2617 \pm 1315$ & 283 & $246-320$ \\
\hline Námafjall_WS & Na_WS [6], [7] & Well steam & Direct sampling & 99.8 & 0.08 & $7.6 \cdot 10^{-2} \pm 2.6 \cdot 10^{-2}$ & & & 1.2 & $1428 \pm 566$ & 302 & $246-320$ \\
\hline Námafjall & $\mathrm{Na}[6],[7]$ & Fumarole & Direct sampling & $99.8 \pm 0.1$ & $0.13 \pm 0.04$ & $3.5 \cdot 10^{-2} \pm 3 \cdot 10^{-2}$ & & & $8 \pm 11$ & $810 \pm 220$ & 95 & \\
\hline Nesjavellir_WW & Ne_WW [6] & Well waters & Direct sampling & 99.9 & 0.1 & $3.7 \cdot 10^{-2} \pm 1.9 \cdot 10^{-2}$ & & & $4.4 \pm 3$ & $972 \pm 188$ & 281 & $271-290$ \\
\hline Nesjavellir_WS & Ne_WS [6] & Well steam & Direct sampling & 99.7 & $0.2 \pm 0.1$ & $9.4 \cdot 10^{-2} \pm 3.8 \cdot 10^{-2}$ & & & $3.4 \pm 3$ & $490 \pm 204$ & 284 & $271-290$ \\
\hline Nesjavellir & $\mathrm{Ne}[6]$ & Fumarole & Direct sampling & $99.5 \pm 0.1$ & 0.4 & $6.7 \cdot 10^{-2} \pm 2 \cdot 10^{-2}$ & & & $6.5 \pm 1$ & $241 \pm 19$ & 95 & \\
\hline Reykjanes_WW & Re_WW [6] & Well waters & Direct sampling & 100 & 0.02 & $9 \cdot 10^{-4}$ & & & 21.9 & 5066 & 248 & $248-285$ \\
\hline Reykjanes_WS & Re_WS [6], [7], [9] & Well steam & Direct sampling & 98.9 & 0.09 & $3.6 \cdot 10^{-3} \pm 4.5 \cdot 10^{-4}$ & & & $24.2 \pm 1$ & $1175 \pm 201$ & 267 & $248-285$ \\
\hline Reykjanes & $\operatorname{Re}[5],[6],[7]$ & Fumarole & Direct sampling & $98.2 \pm 2.8$ & $1.7 \pm 2.7$ & $5.6 \cdot 10^{-2} \pm 1 \cdot 10^{-1}$ & & & $66.8 \pm 47$ & $299 \pm 225$ & 95 & \\
\hline Surtsey & $\mathrm{Su}[1]$ & Fumarole & Direct sampling & $87.8 \pm 4$ & $4.1 \pm 3$ & $4.1 \cdot 10^{-1} \pm 2.8 \cdot 10^{-1}$ & $3.03 \pm 0.62$ & & $1.2 \pm 0.8$ & $52.6 \pm 58$ & 1125 & \\
\hline Svartsengi_WW & Sv_WW [6] & Well waters & Direct sampling & 100 & 0.02 & $3.8 \cdot 10^{-4} \pm 1.7 \cdot 10^{-4}$ & & & $45.6 \pm 11$ & $6654 \pm 1029$ & 240 & 240 \\
\hline Svartsengi_WS & Sv_WS[6], [7], [9] & Well steam & Direct sampling & 99.9 & 0.08 & $1.8 \cdot 10^{-3} \pm 1.2 \cdot 10^{-3}$ & & & $51.8 \pm 17$ & $1861 \pm 1264$ & 240 & 240 \\
\hline Theistareykir & $\operatorname{Th}[5],[7]$ & Fumarole & Direct sampling & $99.4 \pm 0.1$ & $0.3 \pm 0.1$ & $7.6 \cdot 10^{-2} \pm 3 \cdot 10^{-2}$ & & & $4.1 \pm 1$ & $386 \pm 117$ & 95 & \\
\hline Torfajökull & To [5], [7] & Fumarole & Direct sampling & $99.6 \pm 0.3$ & $0.3 \pm 0.2$ & $2.6 \cdot 10^{-2} \pm 3.0 \cdot 10^{-2}$ & & & $20 \pm 10$ & $408 \pm 204$ & 95 & \\
\hline Vonarskard & Vo [5] & Fumarole & Direct sampling & 99.1 & 0.4 & 0.1 & & & 3.5 & 274 & 95 & \\
\hline
\end{tabular}

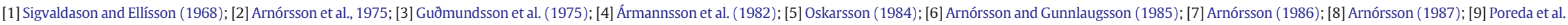
(1992); [10] Arnórsson (1995); [11] Bjarnason (2000); [12] Burton et al. (2010); [13] Guðjónsdóttir (2014); [14] Burton et al. (2014); [15] Gíslason et al. (2015); [16] llyinskaya et al. (2015); [17] Pfeffer et al. (2015); [18] this study. 
Table 3) ratios relative to hydrothermal steam samples, and prevalence of $\mathrm{SO}_{2}$ over $\mathrm{H}_{2} \mathrm{~S}$. Information on the chemistry of high-temperature magmatic gas emissions in Iceland is limited, and includes measurements made during only three volcanic eruptions (Surtsey in 1963 from Sigvaldason and Ellísson, 1968; Eyjafjallajökull/Fimmvörduháls in 2010 from Burton et al., 2010; and Bárðarbunga/Holuhraun in 2014-2015 from Burton et al., 2014; Gíslason et al., 2015; Pfeffer et al., 2015) (Table 3). Note that some of the most $\mathrm{H}_{2} \mathrm{O}$-rich gases emitted during the early stages of the Bárðarbunga/Holuhraun eruption (Fig. $1 b)$ have been interpreted to reflect some extent of meteoric water entrainment in the plume (measured by the Multi-GAS) (Gíslason et al., 2015).

\section{Models of magmatic scrubbing: Sequence of computational operations}

In order to explore scrubbing at different T-P conditions, we combined reaction path models (Sections 2.1, 2.2 and Appendices A and B) with degassing calculations (Section 2.3), to finally derive the chemical composition of both aqueous and gas phases formed after reaction of magmatic gases with hydrothermal solutions and host rock.

The typical sequence of computational operations is illustrated in Fig. 2. For a given model run type (e.g. "A_1-11" in Table 2), several distinct runs were carried out (see number of runs in Table 2). At the first simulation run, Run_1 in Fig. 2 (e.g. A_1 run in Table 2), $n_{g, r u n \_1}$ moles of initial gas $\left(T_{g}=800{ }^{\circ} \mathrm{C}\right.$; Table 1$)$ are added to $1 \mathrm{~kg}$ of initial aqueous solution $\left(T_{w}=4.1^{\circ} \mathrm{C}\right.$; Table 1$)$ while $n_{s}$ moles of solid reactant are avail-

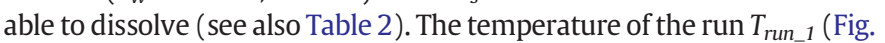
2 ) is either derived by enthalpy balance (for low-T model runs; see Appendix A) or a-priori fixed to fit geothermal reservoir temperatures (for high-T model runs).

During the EQ6 model reaction path, gas and solids dissolve (at their specific rates; see Appendix A) and secondary solid phases precipitate (if reaching over-saturation). At the end of the run, EQ6 returns the chemical composition of a new aqueous solution (aqueous solution_1; Fig. 2) that, due to dissolution of the initial gas, has higher gas content than the initial aqueous solution (Fig. 2). If a state of overpressurization $\left(\right.$ Pgas $_{\mathrm{TO}}>\mathrm{P}_{\text {run }}$ ) is reached, the excess gas is separated to a gas phase by single-step degassing, until a new equilibrium is attained $\left(\right.$ Pgas $_{\text {TOT }}=P_{\text {run }}$ ) (Section 2.3). The chemical compositions of the released gas phase (separated gas phase_1 in Fig. 2) and of the degassed liquid (degassed aqueous solution_1; Fig. 2) are then obtained, the latter being then used as starting aqueous solution (Fig. 2) in the following simulation run (Run_2; Fig. 2).

In Run_2 of the same model run type, $n_{g, r u n \_2}$ moles of initial gas (see also $n_{\text {g,run_n }}$, in Table 2 ) are added to the starting aqueous solution (the solid reactant is kept at same amount as in Run_1; see also Table 2). The new reaction path calculations carried out in Run_2 (e.g. A_2 run in Table 2) occur at temperature $T_{\text {run_2 }}$. At the end of this run, aqueous solution_2 is outputted by EQ6, which is again degassed in a singlestep degassing (at $T_{\text {run_2 }}$ ) in order to derive degassed aqueous solution_2 and separated gas phase_2 (in Fig. 2). Each EQ6 run simulation is run out until a target temperature is reached (see Appendix A).

\section{Modeling results}

We report results for 8 different model run types, which we use to explore magmatic gas scrubbing at different $P$, $T$ conditions. As summarized in Table 2, all runs of a given type (e.g., A_1 to A_11; Table 2) are initialized with identical input parameters (initial gas, solid reactants), except for the amount of initial gas added to the starting aqueous solution (Fig. 2 and Table 2).

Run types A to D (Table 2) are all designed to investigate reaction paths in the 14 to $106{ }^{\circ} \mathrm{C}$ temperature range, but are conducted using different (relative) gas dissolution rates (Table 2; see Appendix A); these low-T model runs aim therefore at investigating scrubbing in shallow groundwater conditions.

Run types E to $\mathrm{H}$ (high-T model runs; Table 2) are executed at temperatures of either 200 or $250{ }^{\circ} \mathrm{C}$, to explore the effect of scrubbing at hydrothermal reservoir conditions.

The same initial aqueous solution (Holm et al., 2010) and initial gas (Burton et al., 2010) (Table 1) are used throughout. We initialise our simulations with two distinct solid reactants, a basaltic glass from Hekla (model runs B-D; Table 2) and a basaltic glass from the Krýsuvík geothermal field (model runs E-H; Table 2) (Table 1). The total amount of solid reactants available to dissolve in each run (Table 2) were based on inter-granular porosities, and assuming pore spaces of the solid reactant are water-saturated (See Appendix A). Only minor fractions of the available rock is actually dissolved at the end of the runs $(<2.85$ and $<0.35 \mathrm{~mol}$ at $200^{\circ}$ and $250^{\circ} \mathrm{C}$, respectively; Table 2). Model runs A_111 (Table 2) are conducted in the absence of solid reactant to explore scrubbing in a simple gas-water system. More details on the initialization of the runs are given in Appendix A.

\subsection{Aqueous solutions}

Figs. 3-4 illustrate some selected results of our model simulations. These Figures demonstrate, in particular, the physical-chemical properties and chemical compositions of the model aqueous solutions (aqueous solution_ $n$ in Fig. 2). We identify with circles model aqueous solutions derived from low-T (A-D) model runs, while stars represent aqueous solutions from high-T (E-H) model runs.

The model evolution of $\mathrm{pH}$ in the aqueous solutions is illustrated in Fig. 3a. In the low-T model run, the $\mathrm{pH}$ of model aqueous solutions decreases as increasing amounts of initial gas are stepwise added to the system. The model aqueous solutions are far more acidic $(\mathrm{pH}<4)$ than the initial aqueous solution (blue square in Fig. 3a), reflecting the dissolution of acidic magmatic gases. Model runs A_1-11, in which no solid reactants has been made available to interact with the starting aqueous solution (see Table 2 ), produce aqueous solutions that are more acidic ( $\mathrm{pH}$ from 2 to 1 ) than those obtained in model runs $\mathrm{B}-\mathrm{D}$ ( $\mathrm{pH}$ from 4 to 2 ). In contrast, neutral to basic ( $\mathrm{pH}$ of $\sim 7.8-8.5$ ) aqueous solutions are obtained at temperatures of 200 and $250{ }^{\circ} \mathrm{C}$ (E-H model runs; Table 2), due to the increased buffering role of dissolving solid reactants.

Likewise $\mathrm{pH}$, the redox conditions of our model aqueous solutions also exhibit drastic modifications (Fig. 3b) in consequence of gaswater-rock interactions. While in high-T model runs the oxygen fugacity (expressed as $\log f_{\mathrm{O} 2}$ ) was externally fixed by the empirical relation of D'Amore and Panichi (1980), this parameter was left free to vary during the low-T simulation runs. In these latter cases, very reducing redox conditions ( $\log f_{\mathrm{O} 2} \sim-70$ ) are seen in response to the first addition (run_1; Fig. 2) of magmatic gas (initial gas) to the initial aqueous solution (initial $\log f_{\mathrm{O} 2}=-0.6$ ) (see Fig. 3b). Afterwards, along the sequence of simulation runs (of a given model run type), the $\log f_{\mathrm{O} 2}$ of aqueous solutions progressively increases with temperature, up to $\log f_{\mathrm{O} 2} \sim-47$ at $106^{\circ} \mathrm{C}$. This model evolution falls closely to the theoretical curve predicted by the $\mathrm{H}_{2} \mathrm{~S}-\mathrm{SO}_{2}$ redox buffer of Giggenbach (1987).

The chemistry of the aqueous solutions also evolves along the model reaction paths (Fig. 4). The relative abundances of major dissolved anions (Fig. 4a) and cations (Fig. 4b), in particular, exhibit substantial chemical modifications in response to the progressive addition of magmatic gas to aqueous solutions. In low-T model runs, as exemplified in Fig. 4a by run D_1-5, model solutions evolve along a compositional trend, from the carbon-dominated composition of the initial aqueous solution (blue square) towards compositions enriched in sulphur $\left(\mathrm{S}_{\mathrm{TOT}}=\right.$ $\mathrm{S}^{-}+\mathrm{SO}_{4}^{2-}$ ) and, to a minor extent, chlorine (as $\mathrm{Cl}^{-}$) (Fig. 4a). Overall, this compositional evolution reflects the rapid response of aqueous solution chemistry to dissolution of the S-Cl-rich initial gas. In contrast, in the same temperature range (from 14 to $106{ }^{\circ} \mathrm{C}$ ), no evident change is 
observed in dissolved cations (Fig. 4b): all modelled aqueous solutions plot in the proximity of the $\mathrm{Mg}$ corner, and overlap with the composition of the initial aqueous solution.
Results of the high-T model runs highlight that the addition of the initial gas at $200{ }^{\circ} \mathrm{C}$ and $250{ }^{\circ} \mathrm{C}$ guides the model reaction paths towards net relative enrichments in dissolved $\mathrm{Cl}$ (see stars in Fig. 4a) at the
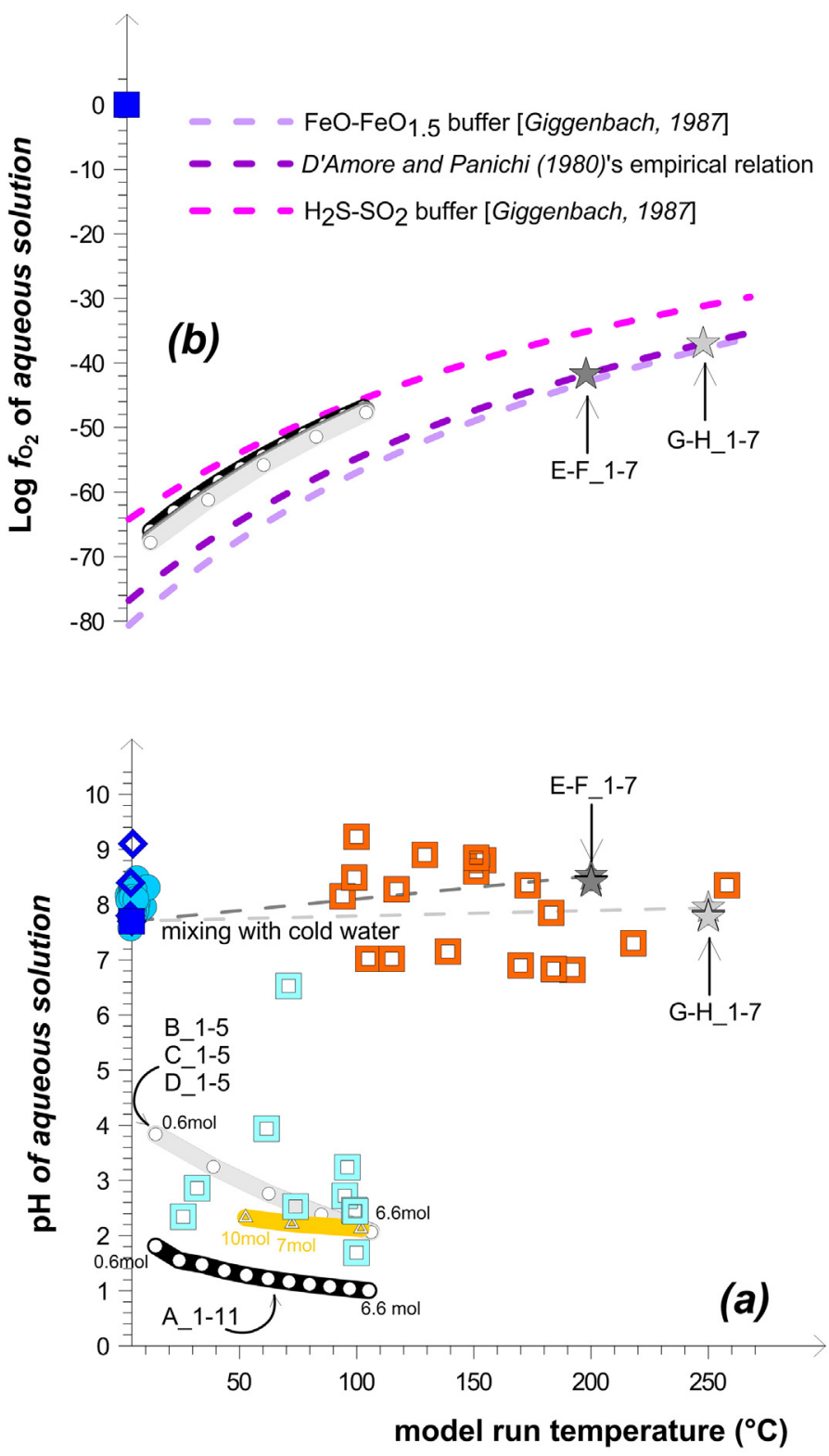

initial aqueous solution

Hekla spring [3]

Hekla river waters [2]

Krýsuvík shallow waters [4]

Krýsuvík reservoir waters [1], [5]

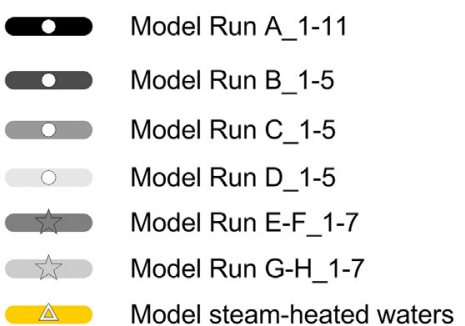

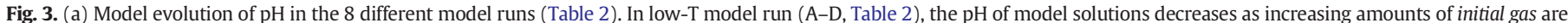

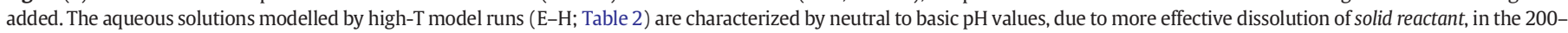

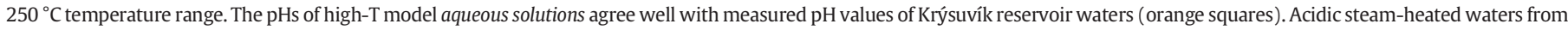

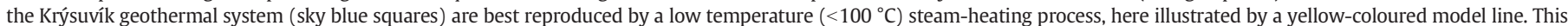

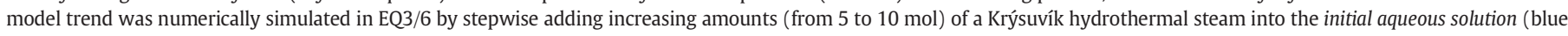

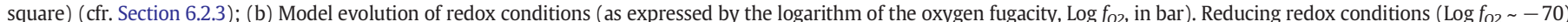

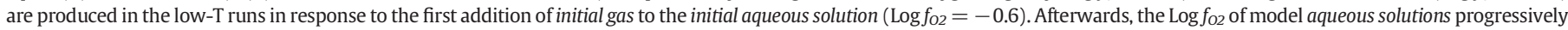

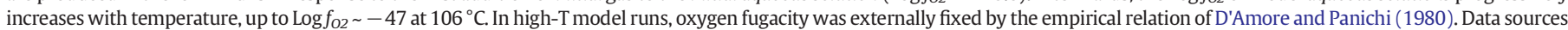
in Figures (a): Arnórsson et al., 1975 [1]; Flaathen and Gíslason, 2007 [2]; Holm et al., 2010 [3]; Markússon and Stefánsson, 2011 [4]; Guðmundsson et al., 1975 [5]. 
expenses of sulphur and carbon. The latter are essentially removed by precipitation of S- (pyrite) and C-rich (carbonates) secondary minerals from model solutions at neutral to basic pHs. In terms of dissolved cations, $200-250{ }^{\circ} \mathrm{C}$ modelled solutions have compositions that contrast with those obtained in low-T model runs. The high-T aqueous solutions exhibit the characteristic Mg-depletion trend, and alkali enrichment patter, that is typical of "mature" hydrothermal fluids having progressed towards a state of equilibrium (Giggenbach, 1988). Our modelled $\mathrm{Na} / \mathrm{K}$ ratios (see stars in Fig. 4b), in particular, are well consistent with those predicted at full-equilibrium conditions at run temperatures (as given by the full equilibrium line of Giggenbach, 1988).

\subsection{Gas phase}

The model-predicted evolution of gas phase composition is shown in Figs. 5-6.

In the low-T runs (A-D; Table 2), the model aqueous solutions reach over-saturation $\left(\mathrm{Pgas}_{\mathrm{TOT}}>\mathrm{P}_{\text {run }}\right.$ ) after addition of $\sim 0.6 \mathrm{~mol}$ of gas (e.g., at $\sim 14^{\circ} \mathrm{C}$ ) (Fig. 5). For all the runs at $\mathrm{T}>14^{\circ} \mathrm{C}$, we calculate therefore the model evolution of the separated gas phase, e.g. the gas phase obtained after single-step degassing of the over-pressurized aqueous solutions formed by interaction with the initial gas (Section 2.3). Fig. 6 shows these compositions, and demonstrates that these are manifestly dominated by $\mathrm{CO}_{2(\mathrm{~g})}$ (from 97 to $74 \%$ in vol.) for temperatures $\leq 80{ }^{\circ} \mathrm{C}$; at higher temperatures $\left(80-106{ }^{\circ} \mathrm{C}\right)$, water vapor exceeds $\mathrm{CO}_{2(\mathrm{~g})}$ to become the main gas species $\left(\mathrm{H}_{2} \mathrm{O}_{(\mathrm{g})}=60-85\right.$ vol.\%) (Fig. 6). $\mathrm{H}_{2} \mathrm{~S}_{(\mathrm{g})}$ and $\mathrm{HCl}_{(\mathrm{g})}$ are minor constituents of the modeled separated gas phase over the entire $14-106{ }^{\circ} \mathrm{C}$ temperature range (Fig. 6). At all $\left(\mathrm{T}<106{ }^{\circ} \mathrm{C}\right)$ conditions explored, $\mathrm{H}_{2} \mathrm{~S}_{(\mathrm{g})}$ and $\mathrm{HCl}_{(\mathrm{g})}$ concentrations increase with increasing temperatures, implying more effective gas phase transport of both species in gas-rich environments. In contrast to $\mathrm{CO}_{2(\mathrm{~g})}$ and $\mathrm{H}_{2} \mathrm{O}_{(\mathrm{g})}$, which exhibit overlapping trends for all low-T (A-D) run types, $\mathrm{H}_{2} \mathrm{~S}_{(\mathrm{g})}$ and $\mathrm{HCl}_{(\mathrm{g})}$ appear more sensitive to the conditions at which model runs are conducted (see Table 2 ). For examples, $\mathrm{HCl}_{(\mathrm{g})}$ concentrations are substantially different depending on if a solid reactant is present or absent in the simulation runs (Fig. 6): model run type A (Table 2), in which the solid reactant is not present, outputs modeled $\mathrm{HCl}_{(\mathrm{g})}$ concentrations that are more than one order of magnitude larger than obtained (at same temperature) in model run types B-D (solid reactants present; Table 2). Clearly, $\mathrm{HCl}_{(\mathrm{g})}$ is more effectively transported in the gas phase in the extremely acidic conditions (Fig. 3) that prevail in the solid reactant-free run. Similarly, the different input conditions of model run types (Table 2) lead to subtle (but still appreciable) variations in $\mathrm{H}_{2} \mathrm{~S}_{(\mathrm{g})}$ concentrations (Fig. 6). A comparison of results of model runs types $\mathrm{B}-\mathrm{D}$, all made using the same input solid reactants (Table 2), shows that (at any given temperature), the $\mathrm{H}_{2} \mathrm{~S}_{(\mathrm{g})}$-richest gas is obtained where the gas dissolution rate is higher ( 26 times rock dissolution rate, model runs D; Table 2).

In the high-T run types (E-H), gas over-saturation is reached after $\sim 0.2\left(200{ }^{\circ} \mathrm{C}\right)$ to $\sim 0.8\left(250{ }^{\circ} \mathrm{C}\right)$ moles of gas are added to $1 \mathrm{~kg}$ of initial aqueous solution (Fig. 5 ). In the gas-poor regime, e.g. below the saturation threshold ( of $0.2-0.8 \mathrm{~mol}$ ), all gas added to model aqueous solutions remains in dissolved form. At higher gas contents, e.g. above the saturation threshold ( $>0.2$ or $>0.8 \mathrm{~mol}$ ), gas species partition between the aqueous solutions and a free vapor phase. In this latter case, the gasphase composition of coexisting aqueous and vapor phase is computed (by single-step degassing, Eq. (2)) and plotted in Fig. 6.

The dissolved gas compositions of model aqueous solutions, at both 200 and $250{ }^{\circ} \mathrm{C}$, contain relatively small amounts of dissolved $\mathrm{CO}_{2}$ $\left(0.03-0.2\right.$ vol.\%), $\mathrm{H}_{2} \mathrm{~S}\left(\sim 6 \cdot 10^{-4}-0.05\right.$ vol.\%) and $\mathrm{HCl}\left(\sim 8 \cdot 10^{-12}\right.$ $3 \cdot 10^{-8}$ vol.\%). The lowest dissolved gas concentrations are of course obtained in the gas-poor model regime. The compositions of the separated gas phases (calculated only at conditions where a free gas-phase is formed) are also $\mathrm{H}_{2} \mathrm{O}$-dominated $\left(\mathrm{H}_{2} \mathrm{O}_{(\mathrm{g})} \sim 81-83\right.$ vol.\%), but yet more rich in $\mathrm{CO}_{2(\mathrm{~g})}\left(\sim 15-19\right.$ vol.\%) and $\mathrm{H}_{2} \mathrm{~S}_{(\mathrm{g})}(\sim 0.1-2$ vol.\%) than in the gas under-saturated conditions. The neutral $\mathrm{pH}$ conditions of the
200-250 ${ }^{\circ} \mathrm{C}$ model runs (Fig. 3a) result in lower fractions of $\mathrm{HCl}_{(\mathrm{g})}$ (from $7 \cdot 10^{-10}$ to $6 \cdot 10^{-8}$ ) in the separated gas phases, relative to 14-106 ${ }^{\circ} \mathrm{C}$ runs (Fig. 6). This model observation is consistent with $\mathrm{HCl}_{(\mathrm{g})}$ being typically undetectable in hydrothermal steam samples (Chiodini and Marini, 1998)..

\subsection{Secondary minerals formed}

A range of secondary mineral phases is allowed to form in the reaction path model runs, when/if reaching saturation in model aqueous solutions. Our low-T model runs predict the formation of large amounts of carbonates and pyrite, which act as sinks of carbon and sulphur from model solutions. In the same model runs, the minerals chalcedony, kaolinite, smectites and zeolites are formed, and therefore control abundance of $\mathrm{Si}, \mathrm{Al}$ and other cations leached from the solid reactant. This mineral assemblage agrees well with observed alteration mineral paragenesis in low-T $\left(<100{ }^{\circ} \mathrm{C}\right)$ hydrothermal fields (Flaathen et al., 2009; Markússon and Stefánsson, 2011; Gysi and Stefánsson, 2011). Calcite and pyrite are also predicted to precipitate in our high-T model runs. In this $200-250{ }^{\circ} \mathrm{C}$ temperature range, chalcedony is replaced by quartz and smectites by chlorite in the model secondary mineral assemblage. High-T zeolite varieties (e.g. wairakie, scolecite), albite, K-feldspar and epidote are also formed in the last stages of the reaction path of our high-T model runs. These alteration mineral assemblages, predicted by our high-T model runs, match well experimental results from Gysi and Stefánsson (2012), and are consistent with the observed distribution of hydrothermal minerals in boreholes from Krýsuvík (Arnórsson et al., 1975) and Krafla (Ármannsson et al., 1982).

\section{Discussion}

Quantitative models of magmatic gas scrubbing have increasingly grown in popularity in the geological literature (Marini and Gambardella, 2005; Symonds and Reed, 1993) since it became clear that reactions between magmatic gases and aquifers play a key control on the chemistry of fluids released by quiescent volcanoes (Doukas and Gerlach, 1995; Symonds et al., 2001). However, due to the complexity of reaction pathways, and the relatively high number of unknown variables, model results have been difficult to match against natural volcanic gas compositions, and model applications to real volcano case studies have remained few in number (Di Napoli et al., 2013; Shinohara et al., 2015; Symonds et al., 2001; Werner et al., 2012).

The EQ3/6 (Daveler and Wolery, 1992; Wolery and Daveler, 1992) reaction path modelling approach (Helgeson, 1968; Helgeson et al., 1969), used here, offers a comprehensive theoretical scheme to quantitatively interpret mechanisms and pathways of the interaction between magmatic gases and meteoric/hydrothermal aqueous solutions. One major advantage offered by EQ3/6 is its flexibility, including the possibility to initialise runs with a set of input parameters including mass, chemical composition and reaction thermodynamic/kinetic data of all the involved reactants that can be adapted to real volcano conditions. In this work, we show that EQ3/6 model runs, if suitably initialised with a proper set of input parameters (Tables 1-2), generate results that are in fair agreement with measured fluid emissions (gas and thermal water) from Icelandic volcanoes.

\subsection{Scrubbing in groundwater environments}

Our low temperature $\left(<106{ }^{\circ} \mathrm{C}\right)$ model runs aim at quantitatively modelling scrubbing of magmatic gases at shallow groundwater conditions. The separated gas phases outputted by our simulations (Fig. 6) correspond to the gases that would escape from aqueous solutions after they have interacted with (and have become enriched in) magmatic gases. Low-T simulations predict a range of separated gas compositions (Fig. 6), depending on temperature, regime (high gas vs. low gas) and 


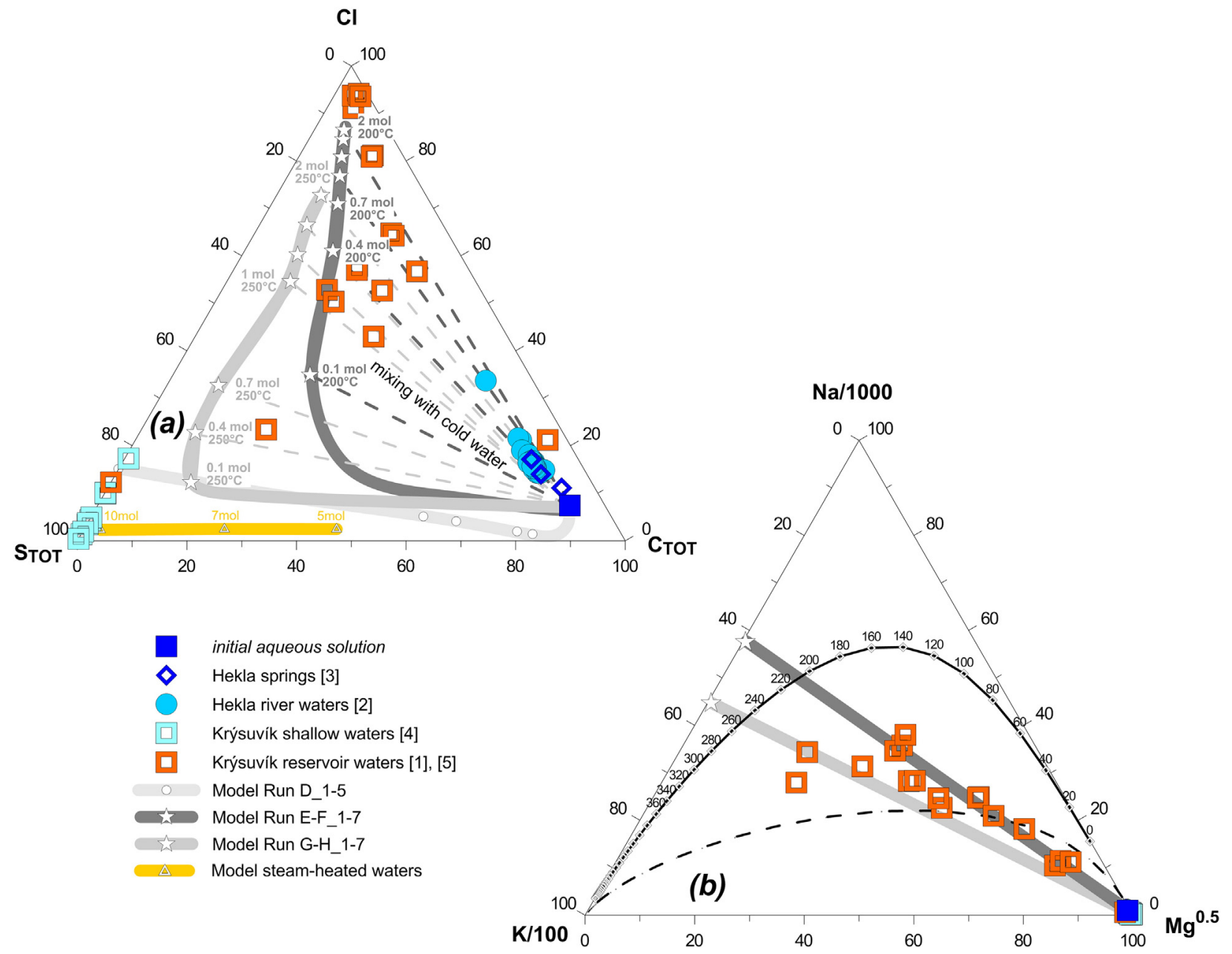

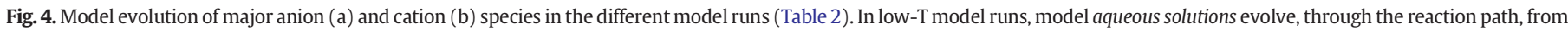

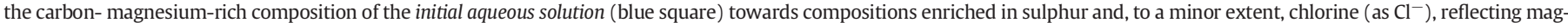

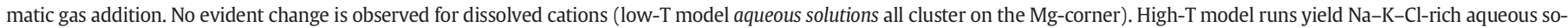

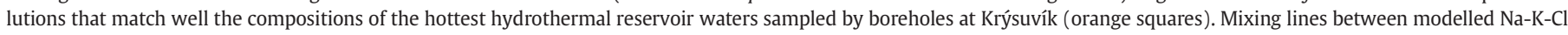

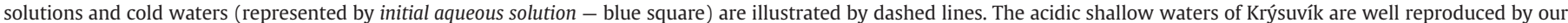
steam-heating model line (see caption of Fig. 3).

phase relations (gas + water vs. gas + water + rock) at which reactions occur.

To test if these models offer a realistic representation of natural conditions, we compare their results with natural gas compositions from Hekla volcano (Ilyinskaya et al., 2015). We initially test if the range of gas $\mathrm{CO}_{2} / \mathrm{S}_{\mathrm{TOT}}$ ratios (with $\mathrm{S}_{\mathrm{TOT}}=\mathrm{H}_{2} \mathrm{~S}_{(\mathrm{g})}+\mathrm{SO}_{2(\mathrm{~g})}$ ) predicted by our low-T model runs match the compositional range of Hekla volcanic gas samples. This comparison is made in Fig. 7, where the characteristic volcanic gas $\mathrm{CO}_{2} / \mathrm{S}_{\text {TOT }}$ ratios ( $\mu \pm 1 \sigma$; Table 3 ) for several volcanic/hydrothermal systems in Iceland (including Hekla) are plotted against the corresponding discharge or deep reservoir temperature. Recent works have demonstrated a negative temperature dependence of the gas $\mathrm{CO}_{2} / \mathrm{S}_{\mathrm{TOT}}$ ratio in several volcanic regions, including Kamchatka (Aiuppa et al., 2012), Italy (Aiuppa et al., 2013), Chile (Tamburello et al., 2014), and Central America (Aiuppa et al., 2014). This dependence, arising from the commonly high $\mathrm{CO}_{2} / \mathrm{S}_{\mathrm{TOT}}$ ratios measured in cold gas samples worldwide, has been suggested to reflect the high extents of sulfur scrubbing that affect the feeding magmatic gas phase at the low-temperature end of the gas population. We show (Fig. 7) that Icelandic gases do not make exception to the general rule, given the very high $\left(>10^{3}\right) \mathrm{CO}_{2} / \mathrm{S}_{\mathrm{TOT}}$ ratios seen in low- $\mathrm{T}\left(<100{ }^{\circ} \mathrm{C}\right)$ gas samples from Hekla and Grímsvötn (Hk and Gr in Fig. 7), all well above the magmatic gas range $\left(\mathrm{CO}_{2} / \mathrm{S}_{\mathrm{TOT}}\right.$ ratios of $1.13 \pm 0.49$ (Holuhraun), $1.2 \pm 0.8$ (Surtsey) and 5 (Fimmvörduháls); see Table 3).
Our low-T models runs (run types A-D) provide quantitative constraints in support to the scrubbing hypothesis. We find that the model-predicted $\mathrm{CO}_{2} / \mathrm{S}_{\mathrm{TOT}}$ ratios in the low-T $\left(4-106{ }^{\circ} \mathrm{C}\right.$; run types AD) separated gas phases form a compositional band, stretching along the upper-left portion of Fig. 7, which perfectly overlaps with the compositions of the Icelandic cold gas samples. Our low-T model runs are designed to represent the natural condition in which magmatic gases are injected into a (meteoric) groundwater system, leading to nearly complete scavenging of soluble $\mathrm{S}$ (and $\mathrm{Cl}$ ) into the aqueous phase (see Fig. 6). Therefore, the general agreement between model and observations confirm the conclusion (Ilyinskaya et al., 2015) that present-day Hekla gas emissions are the residual gases formed after extensive scrubbing of a deeply supplied magmatic gas phase into the volcano groundwater system. We here extend this argument to Grímsvötn (Gr in Fig. 7) (measurements made at the Saltarinn hydrothermal site) where compositions (similar to Hekla) point to the occurrence of compatible processes (Fig. 7). We also note that gas compositions from Eldfell volcano (El in Fig. 7), in spite of their high discharge temperatures (257 ${ }^{\circ} \mathrm{C}$; Table 3 ), exhibit $\mathrm{CO}_{2} / \mathrm{S}_{\mathrm{TOT}}$ ratios of $2603 \pm 1977$ (Table 3), similar to those seen at "colder" systems (Hekla and Grímsvötn). We argue that relatively high vent temperatures at Eldfell do not reflect large magmatic gas contributions (which, in light of our model results, appear instead limited), but, rather, are related to residual cooling of the recently formed (Heimaey 1973 eruption) volcanic cone. 

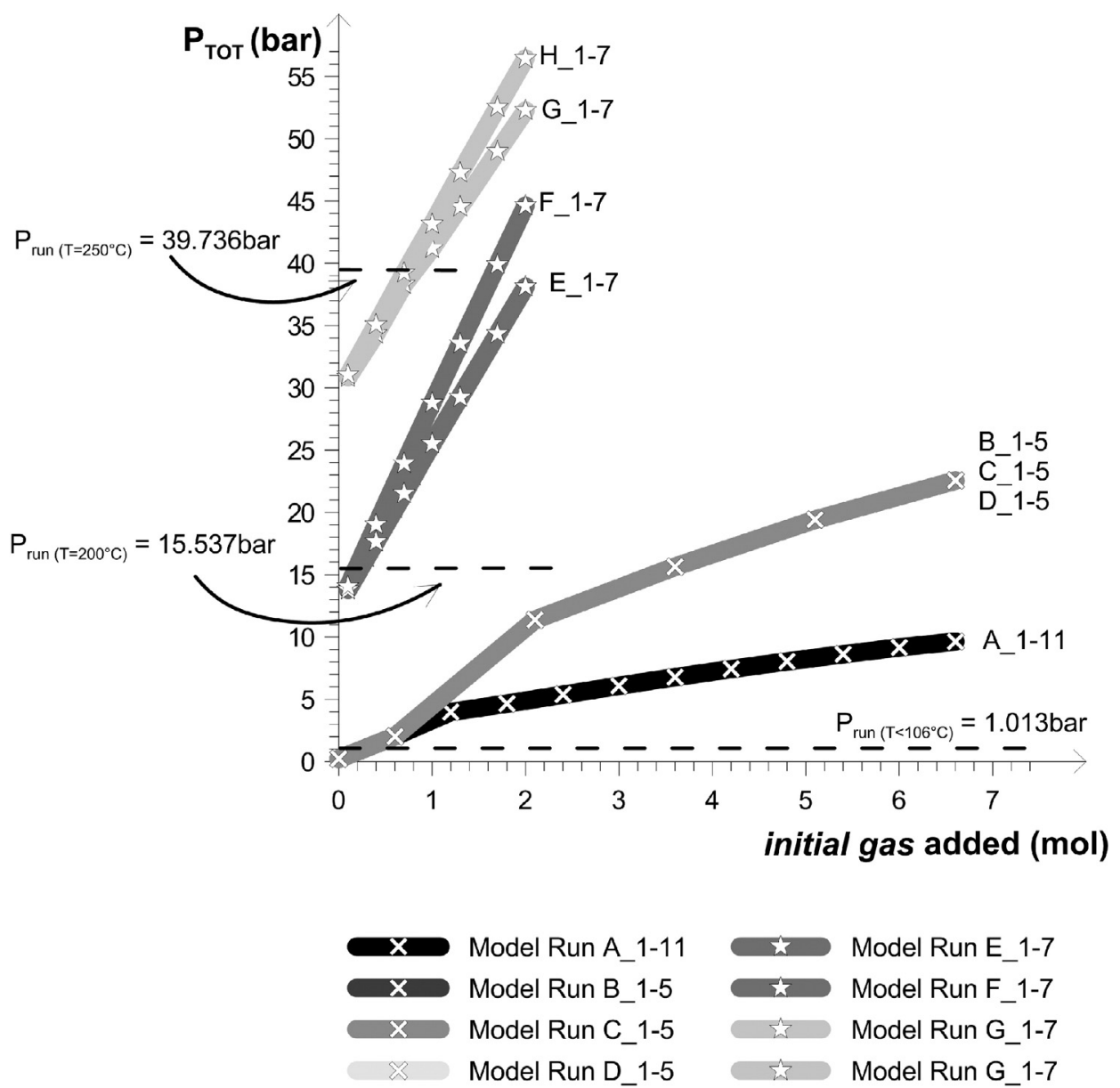

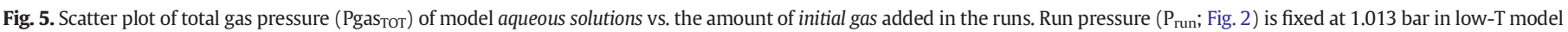

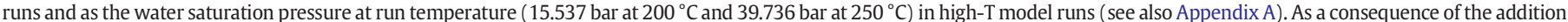

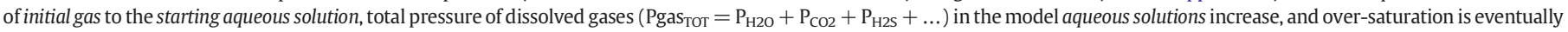

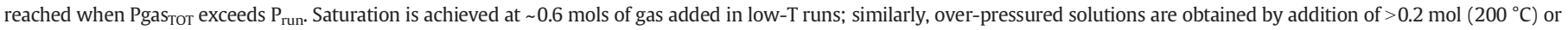
$>0.8 \mathrm{~mol}\left(\right.$ at $250{ }^{\circ} \mathrm{C}$ ).

Fig. 8 extends our model vs. natural gas comparison to the $\mathrm{H}_{2} \mathrm{O}-\mathrm{CO}_{2}$ $\mathrm{S}_{\mathrm{TOT}}$ system. In the diagram, volcanic-hydrothermal gas samples from Iceland form a single compositional array, extending from $(i)$ the $\mathrm{CO}_{2}-$ dominated compositions of "cold gas" samples (Hekla and Grímsvötn) and Eldfell, to ( $i i)$ the low $\mathrm{CO}_{2} / \mathrm{S}_{\mathrm{TOT}}$ ratio compositions of "magmatic gases" (Surtsey, Eyjafjallajökull/Fimmvörduháls and Bárðarbunga/ Holuhraun). Hydrothermal steam samples, both from Krýsuvík and other hydrothermal areas in Iceland, exhibit intermediate $\mathrm{CO}_{2} / \mathrm{S}_{\mathrm{TOT}}$ ratios, and a tendency toward more $\mathrm{H}_{2} \mathrm{O}$-rich compositions $\left(\mathrm{H}_{2} \mathrm{O} / \mathrm{CO}_{2}\right.$ ratios of 2 to 950 ).

In Fig. 8a, the model predicted $\mathrm{H}_{2} \mathrm{O} / \mathrm{CO}_{2}$ vs. $\mathrm{CO}_{2} / \mathrm{S}_{\text {TOT }}$ compositions of low-T model runs (run types A-D) show very nice agreement with observed volcanic gas compositions at Hekla. They also overlap with the natural gas emissions from Eldfell, with volcanic gases emitted at Grímsvötn being only slightly more $\mathrm{H}_{2} \mathrm{O}$-rich. This overall agreement provides additional confidence on our low-T model simulations.

\subsection{Scrubbing in hydrothermal environment}

High-T model runs attempt at investigating scrubbing conditions within hydrothermal systems. To validate the general applicability of the model to real (natural) conditions, we compare (in Figs. 7-8) model outputs with measured reservoir (waters and steam) and surface (e.g., fumaroles and steaming pools) fluids manifestations from Krýsuvík, and other Icelandic hydrothermal systems.

\subsubsection{Model vs. observations: dissolved gases in reservoir fluids}

Our high-T model runs (E-H; Table 3) suggest that, for low gas additions, no gas over-pressure is reached (Fig. 5), so that all gas is retained by model aqueous solutions (here reproducing reservoir waters) in dissolved form (dissolved gas in Figs. 6-7). Geologically, this condition reflects the case in which magmatic gases are totally scrubbed to reservoir fluids during hydrothermal interactions. As more gas is added to the system (Fig. 5), gas species are eventually partitioned between dissolved gas in the aqueous solution and a coexisting equilibrium gas phase. This separated gas phase is obviously more $\mathrm{CO}_{2}$ - and $\mathrm{H}_{2} \mathrm{~S}$-rich than the coexisting aqueous solution (dissolved gas in reservoir water) (Figs. 6 and 8b).

The dissolved gas composition of our modeled solutions (Fig. 6) is compared in Figs. 7 and 8b with compositions of hydrothermal reservoir waters sampled in geothermal boreholes (Ármannsson et al. 1982; Arnórsson, 1986; Arnórsson and Gunnlaugsson, 1985; Arnórsson et al., 1975), which are obvious geological proxies for this process in nature. We find that the dissolved gas compositions obtained in our high- $\mathrm{T}$ (run types E-H) models satisfactorily reproduce the $\mathrm{CO}_{2} / \mathrm{S}_{\text {TOT }}$ ratio range (from 2.3 to 64 ) of hydrothermal reservoir waters (WW in Table 3), which are intermediate between magmatic gas (1.4-5.0) and cold-gas $\left(>10^{3}\right)$ compositional domains (Fig. 7). Obviously, the higher temperatures concur to augmented gas-phase sulfur transport (relative to $\mathrm{CO}_{2}$, and to low-T models). More in the specific, the $250{ }^{\circ} \mathrm{C}$ model predicted $\mathrm{CO}_{2} / \mathrm{S}_{\mathrm{TOT}}$ ratios (4-64) match well the (observed) compositions $\left(\mathrm{CO}_{2} / \mathrm{S}_{\mathrm{TOT}}\right.$ from 4 to 92$)$ of hydrothermal reservoir waters from Krýsuvík (Arnórsson et al., 1975; Guðmundsson et al., 1975) which reservoir 

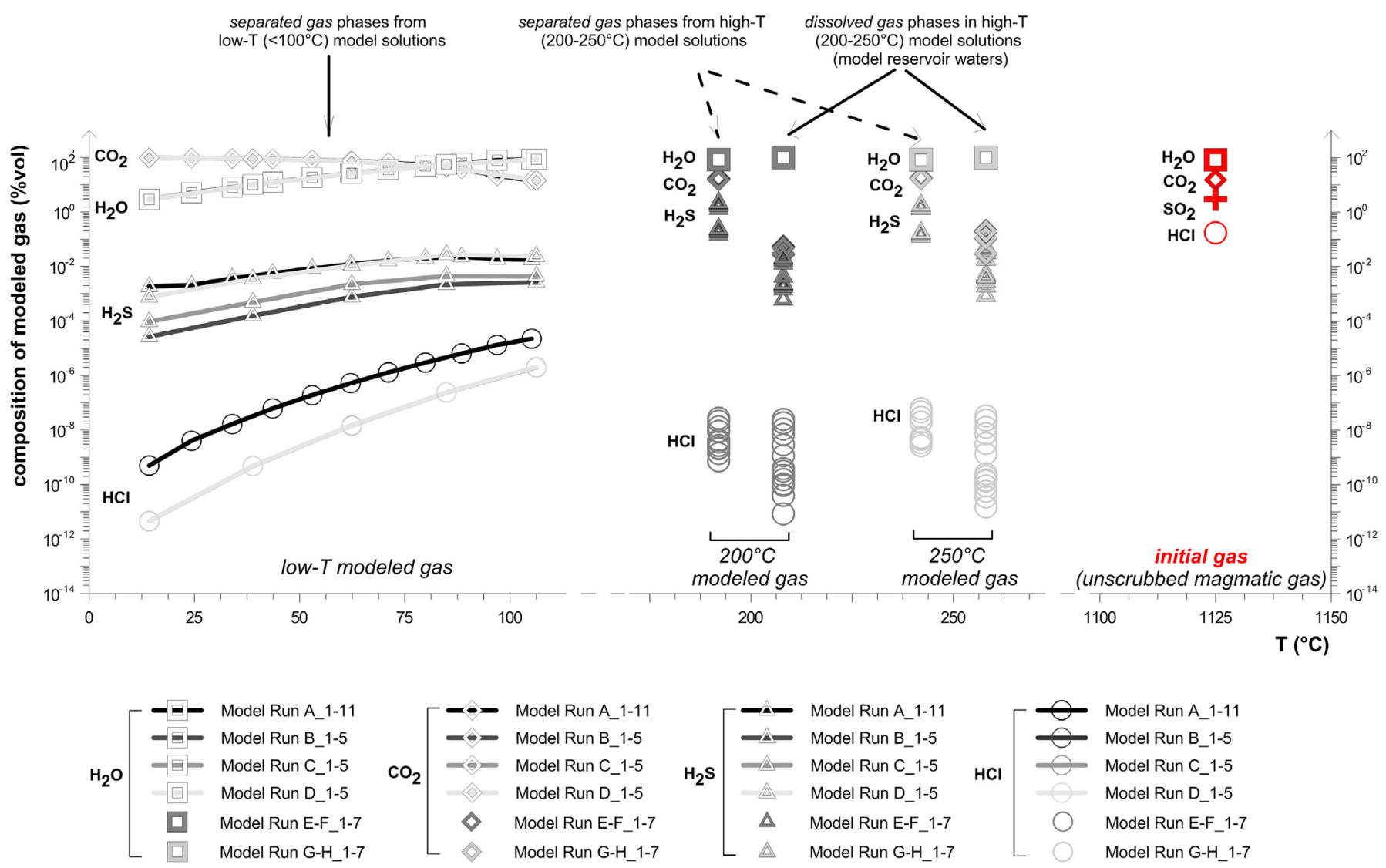

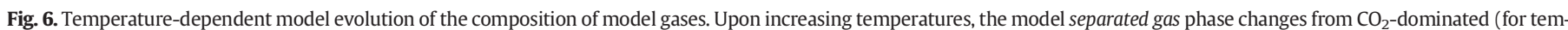

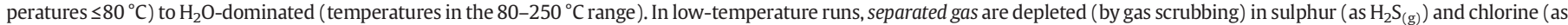

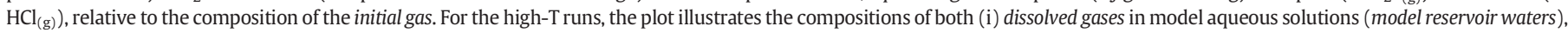

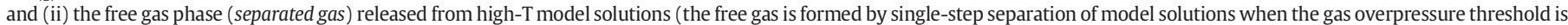
reached; see Section 2.3). Sulfur gas-phase transport is enhanced at $200-250{ }^{\circ} \mathrm{C}$, while $\mathrm{HCl}_{(\mathrm{g})}$ preferentially partitions into aqueous solutions even in such extreme conditions.

temperatures (250-260 ${ }^{\circ} \mathrm{C}$; Arnórsson et al., 1975; Poreda et al., 1992) are in the range of model run temperatures (Fig. 7).

The model also predicts well the range of dissolved gas contents of hydrothermal reservoir waters (WW in Table 3), as seen by the overlapping $\mathrm{H}_{2} \mathrm{O} / \mathrm{CO}_{2}$ ratio compositions of model and natural (reservoir water) fluids in Fig. 8b. Good agreement is observed, in particular, between $\mathrm{H}_{2} \mathrm{O} / \mathrm{CO}_{2}$ ratios compositions of model solutions and reservoir waters from Krafla, Námafjall, Reykjanes and Svartsengi (Fig. 8a and Table 3). Overall, this nice match between modeled and natural compositions testifies for the ability of our models in reproducing real natural conditions of magmatic-hydrothermal interactions. We however find that our models apparently over-estimate (by a factor $\sim 10$ ) the gas content in Krýsuvík reservoir waters (measured $\mathrm{H}_{2} \mathrm{O} / \mathrm{CO}_{2}$ ratios of $\sim 40,000$ vs. $<3600$ in the modeled aqueous solutions). Although we have no unequivocal explanation for this (relatively minor) mismatch, we speculate that some artifact during field sampling of reservoir waters may be implicated, because as stated by Arnórsson et al. (1975) in his Krýsuvík study on borehole fluids ".... when the sample is released from the sampling apparatus and transferred to the sample bottle, some of the volatiles may escape, and the results ... are not considered reliable with respect to these compounds $\left(\mathrm{CO}_{2}\right.$ and $\left.\mathrm{H}_{2} \mathrm{~S}\right)$ ".

6.2.2. The chemistry of hydrothermal steam samples, and the effect of boiling

Our models above reproduce interactions between magmatic gases and hydrothermal waters at reservoir conditions. While such magmatic gas scrubbing reactions, followed by equilibration with host rock minerals (Arnórsson, 1995; Arnórsson et al., 1983; Giggenbach, 1988; Reed and Spycher, 1984; Stefánsson and Arnórsson, 2000, 2002), contribute to determine hydrothermal reservoir fluid compositions, surface steam discharges have instead compositions that are determined by boiling of deep reservoir fluids in the up-flow zone (see Arnórsson, 1986, 1995; Chiodini and Marini, 1998; Giggenbach, 1980, 1993). At Krýsuvík, for example, Arnórsson (1987) used the results of gas sampling surveys, combined with calculations and models, to demonstrate extensive boiling of deep reservoir fluids in their up-flow zone (fractures and faults).

In order to have boiling fully accounted for by our simulations, and therefore reproduce steam discharge compositions (Fig. 8a and c), we used the equations of Chiodini and Marini (1998) to calculate the model compositions of gases formed by single-step boiling of our model aqueous solutions (see Fig. 2), from their initial temperatures of 200-250 ${ }^{\circ} \mathrm{C}$ down to $100{ }^{\circ} \mathrm{C}$. These "boiling" model lines, shown in Figs. 7 and $8 \mathrm{c}$, are found to perfectly overlap with the measured compositions of hydrothermal steam emissions at Krýsuvík, and at other systems in Iceland (e.g., Krafla). This nice agreement provides additional confidence on our model outputs.

\subsubsection{Model vs. observations: major element water chemistry}

The major element (anions/cations) compositions of reservoir and surface waters from Krýsuvík offer an independent test as for the applicability of our models to real case conditions. Our results demonstrate that extents and modes of magmatic gas scrubbing influence the major element composition of the interacting aqueous solutions; the question arises therefore if the model-predicted water chemistry evolution path (Figs. 3, 4) finds evidence in nature.

In a series of key papers, Giggenbach $(1984,1988)$ demonstrated that the addition of hot magmatic gases to aqueous solutions is the 


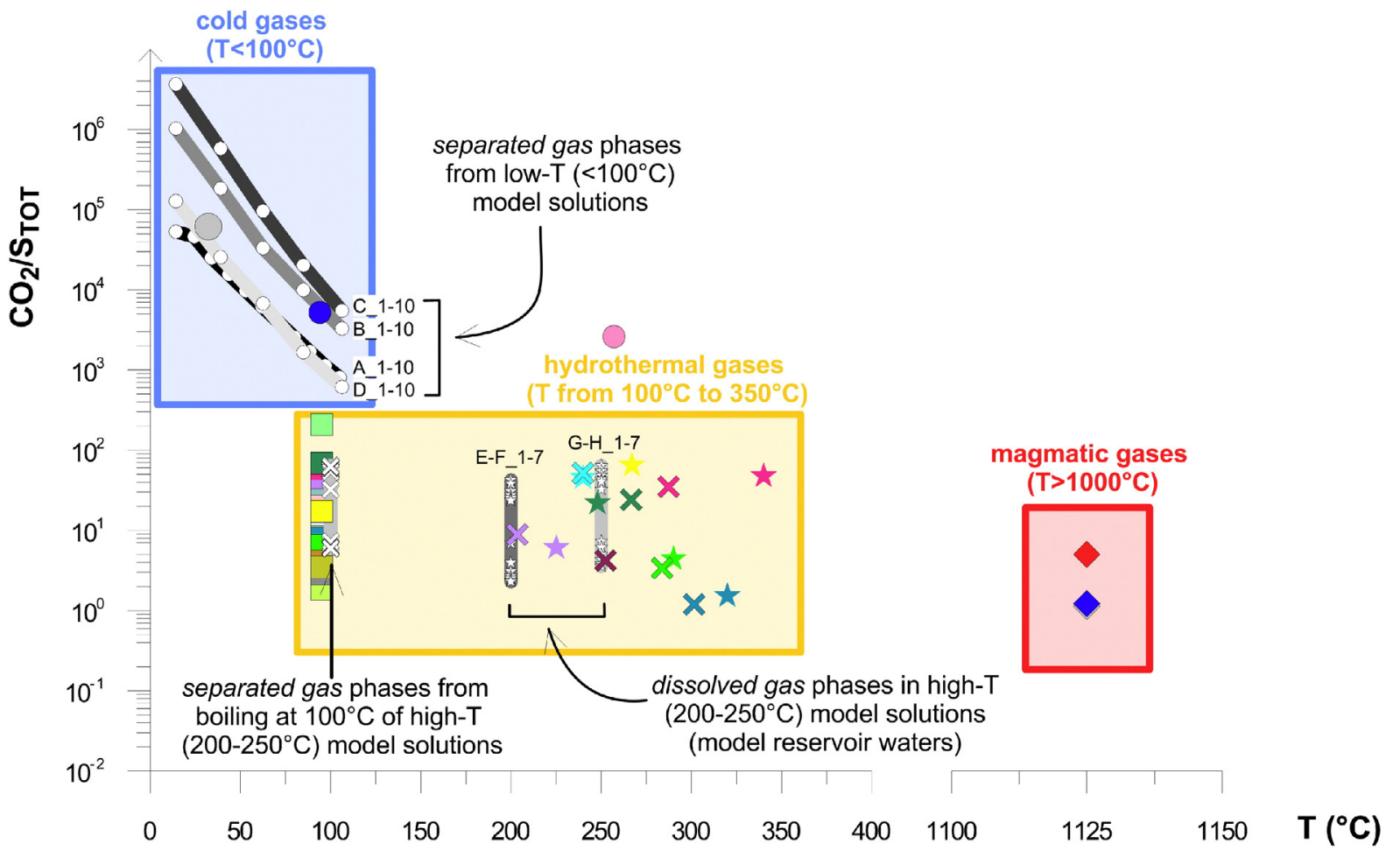

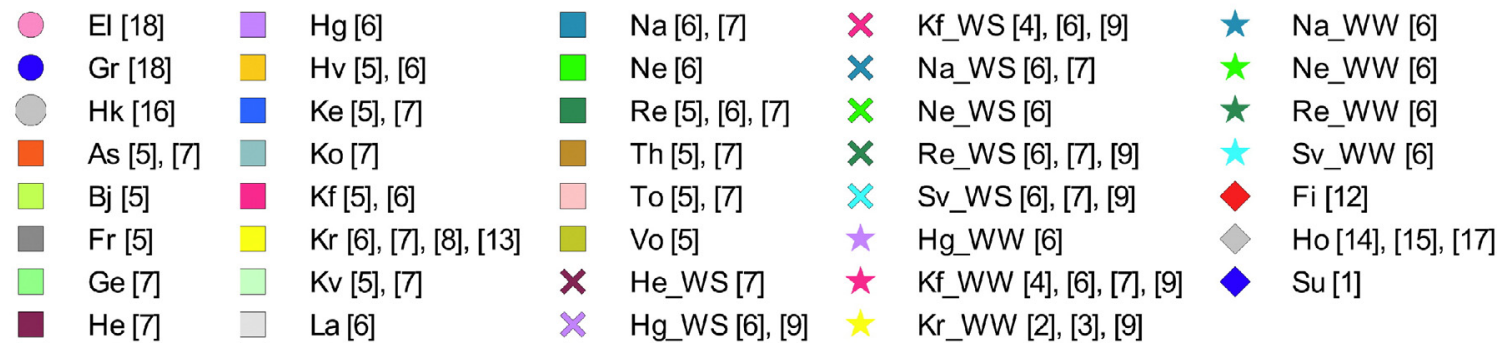

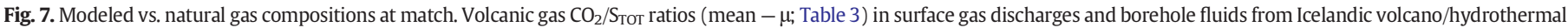

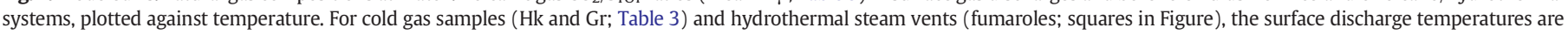

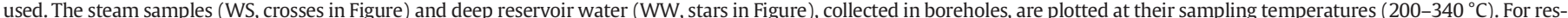

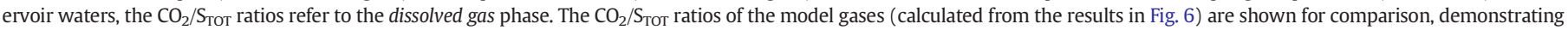

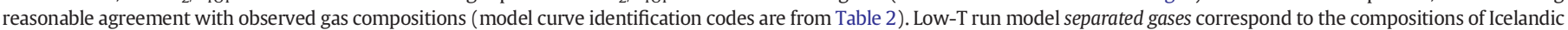

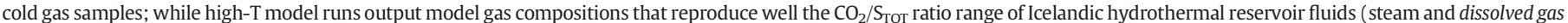
in reservoir waters). Gas ratios in surface fumaroles are matched by compositions of gases formed by boiling at $100{ }^{\circ} \mathrm{C} \mathrm{of} \mathrm{high-T}\left(200-250^{\circ} \mathrm{C}\right)$ model aqueous solutions.

prevalent source of dissolved anion species $\left(\mathrm{SO}_{4}, \mathrm{Cl}, \mathrm{HCO}_{3}\right)$ to volcanic groundwaters/hydrothermal brines, in addition to dissolving hydrothermal minerals (Arnórsson, 1983; Arnórsson et al., 2007). Interaction with hot, acidic magmatic gases also creates favourable conditions for the leaching of major rock forming cations ( $\mathrm{Na}, \mathrm{K}, \mathrm{Ca}, \mathrm{Mg}$ ) from host rock formations. Giggenbach $(1984,1988)$ also distinguished two main environments of gas-water-rock interaction: $(i)$ a shallow groundwater environment, in which dissolution of magmatic/hydrothermal gases into fast circulating meteoric fluids leads to far-from-equilibrium acid leaching of host rock formations, ultimately generating thermal waters with $\mathrm{Ca}-\mathrm{Mg}-\mathrm{SO}_{4}$ ("steam-heated groundwaters"), $\mathrm{Ca}-\mathrm{Mg}-\mathrm{SO}_{4}-\mathrm{Cl}$ ("volcanic groundwaters"), and/or $\mathrm{Mg}-\mathrm{HCO}_{3}$ ("peripheral groundwaters") compositions, and (ii) a deep hydrothermal reservoir environment, in which more prolonged water residence time allows for equilibrium conditions to be reached in the gas-water-rock system, forming the so called "mature" Na-Cl hydrothermal brines (Giggenbach, 1988)..

Fig. 4 demonstrates that our model simulations reproduce well the two distinct (shallow vs. deep) environments of gas-water-rock interaction. The shallow environment of magmatic gas-water-rock interactions is reproduced well by our low-T model runs, in which the modelled aqueous solutions evolve toward more acidic (Fig. 3a), sulphate-rich (Fig. 4a) compositions, starting from the original C-rich composition of the (meteoric-derived) initial solution. Ca and $\mathrm{Mg}$ prevail among cations in these low-T model aqueous solutions (Fig. 4b). Although no thermal water sample from Hekla volcano is available to compare with our model results, we still argue that our low-T modelled aqueous solutions well reflect the general $\mathrm{Ca}-\mathrm{Mg}-\mathrm{SO}_{4}-\mathrm{Cl}$ compositional features of volcanic groundwaters (Giggenbach, 1988, 1993).

The high-T model runs describe a distinct evolutionary path in Fig. 4a; in which, after a transient increase in $\mathrm{S}_{\mathrm{TOT}}$ (due to initial dissolution of the initial gas), the modelled aqueous solutions point toward Cl-rich compositions, because of $\mathrm{S}$ and $\mathrm{C}$ scavenging by hydrothermal minerals (pyrite, calcites and phyllosilicates) as gas-water-rock interactions advance. Concurrently, the modelled aqueous solutions transition, from the initially Mg-rich to more alkali-rich compositions, as the reaction path progresses (Fig. 4b). We conclude that our model results well reproduce 

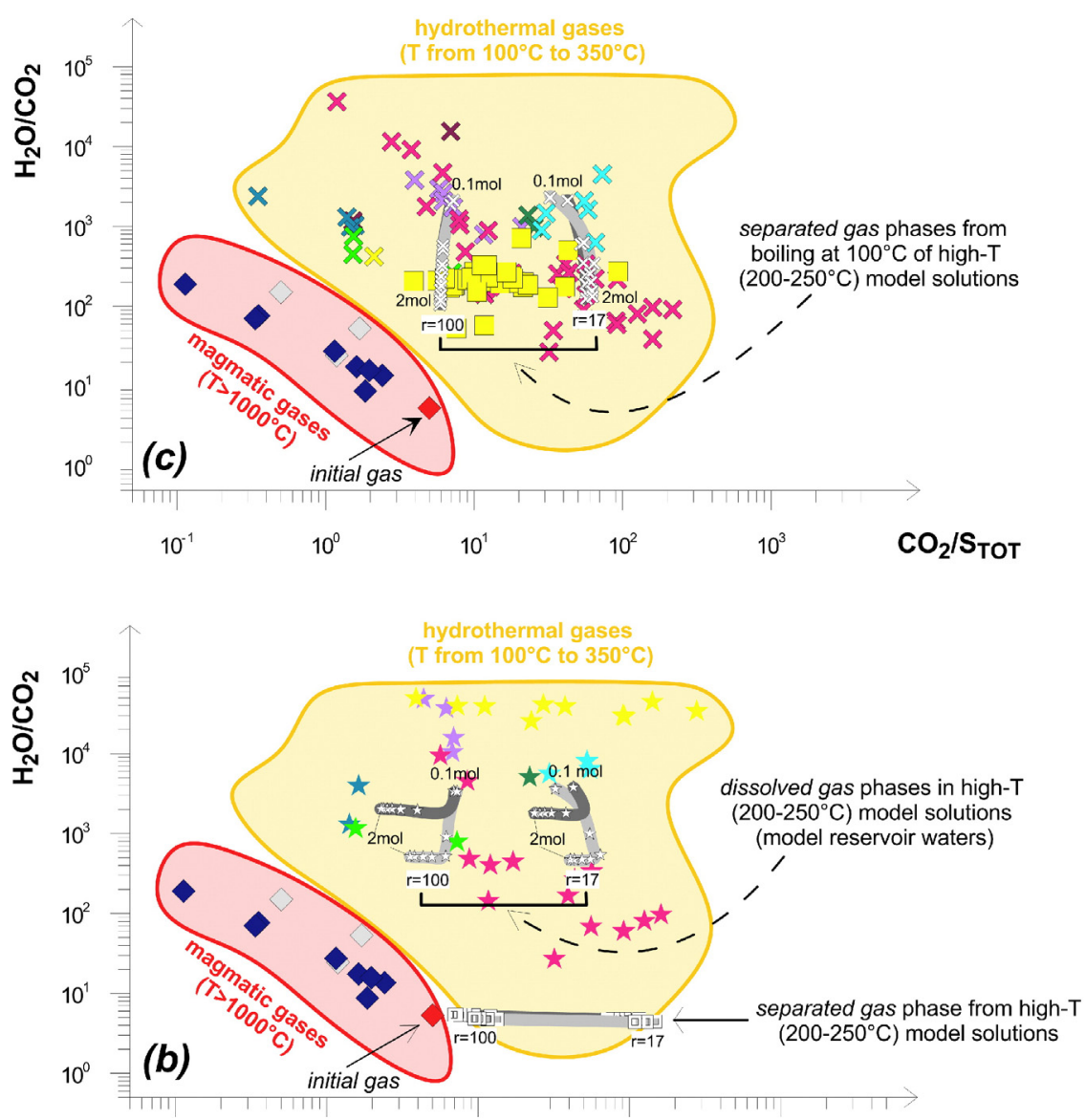

$\begin{array}{llllll}10^{-1} & 10^{0} & 10^{1} & 10^{2} & 10^{3} & \mathbf{C O}_{2} / S_{\text {TOT }}\end{array}$

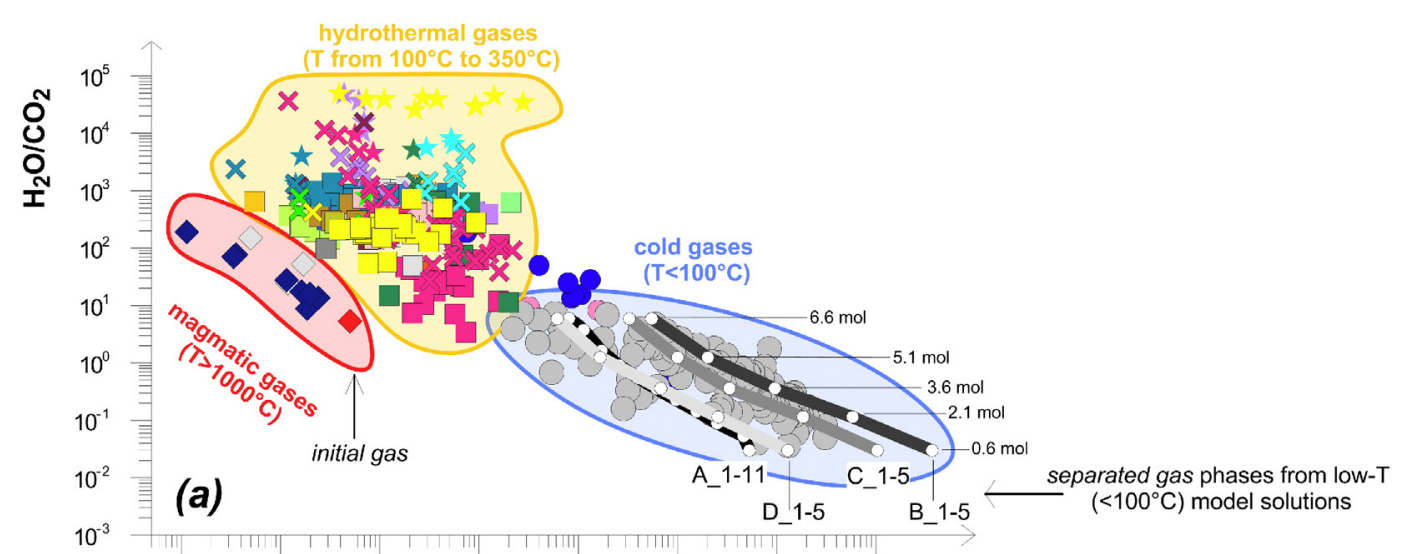

$\begin{array}{lllllllll}10^{-1} & 10^{0} & 10^{1} & 10^{2} & 10^{3} & 10^{4} & 10^{5} & 10^{6} & \mathbf{C O}_{2} / \mathbf{S}_{\text {TOT }}\end{array}$

\begin{tabular}{|c|c|c|c|c|c|c|c|c|}
\hline El [18] & $\mathbf{\square}$ & $\operatorname{Ke}[5],[7]$ & $\square$ & To [5], [7] & $\star$ & Hg_WW [6] & $\infty$ & Model Run A_1-11 \\
\hline $\mathrm{Gr}[18]$ & $\square$ & Ko $[7]$ & $\square$ & Vo [5] & $\star$ & Kf_WW [4], [6], [7], [9] & $-\infty$ & Model Run B_1-5 \\
\hline Hk [16] & $\square$ & Kf [5], [6] & $x$ & He_WS [7] & $\star$ & Kr_WW [2], [3], [9] & $\Leftrightarrow$ & Model Run C_1-5 \\
\hline As [5], [7] & 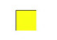 & $\operatorname{Kr}[6],[7],[8],[13]$ & $x$ & Hg_WS [6], [9] & $\star$ & Na_WW [6] & $\infty$ & Model Run D_1-5 \\
\hline Bj [5] & $\sqsubset$ & $\mathrm{Kv}[5],[7]$ & $x$ & Kf_WS [4], [6], [9] & $\star$ & $\mathrm{Ne} \_W W[6]$ & $\square$ & Model Run E-F_1-7 \\
\hline $\operatorname{Fr}[5]$ & $\square$ & La [6] & $s$ & Kr_WS [11] & $\star$ & Re_WW [6] & 可 & Model Run G-H_1-7 \\
\hline $\mathrm{Ge}[7]$ & $\square$ & $\mathrm{Na}[6],[7]$ & $x$ & Na_WS [6], [7] & $\star$ & Sv_WW [6] & $\Rightarrow$ & Model Run E-F_1-7 \\
\hline $\mathrm{He}[7]$ & $\square$ & $\mathrm{Ne}[6]$ & $x$ & $\mathrm{Ne} \_W S[6]$ & & Fi [12] & $\sqrt{25}$ & Model Run G-H_1-7 \\
\hline $\mathrm{Hg}[6]$ & $\square$ & $\operatorname{Re}[5],[6],[7]$ & $x$ & Re_WS [6], [7], [9] & $\diamond$ & Ho [14], [15], [17] & $-x$ & Model Run E-F_1-7 \\
\hline $\mathrm{Hv}[5],[6]$ & 口 & Th [5], [7] & $x$ & Sv_WS [6], [7], [9] & & Su [1] & $-x$ & Model Run G-H_1-7 \\
\hline
\end{tabular}


the maturation path of hydrothermal fluids, from acidic, far-fromequilibrium ("immature" after Giggenbach, 1988) Mg-rich solutions, towards neutral (Fig. 3a) $\mathrm{Na}-\mathrm{K}-\mathrm{Cl}$ aqueous solutions (Fig. 4) similar in composition to the "mature" hydrothermal reservoir waters found at Krýsuvík (Arnórsson et al., 1975) and elsewhere (Arnórsson et al., 1983). Importantly, we find that the $\mathrm{Na} / \mathrm{K}$ ratios predicted by our model runs are not only consistent with those observed in the Krýsuvík hydrothermal reservoir samples, but also correspond to the expected $\mathrm{Na} / \mathrm{K}$ ratios at full-equilibrium conditions (Giggenbach, 1988) at the run temperature.

While, based on our model results, we confirm therefore that magmatic gas scrubbing is well implicated in the generation of $\mathrm{Na}-\mathrm{K}-\mathrm{Cl}$ chemistry of hydrothermal reservoir fluids, we are well aware that additional processes, including mixing and steam condensation, contribute to governing measured water compositions at Krýsuvík (Arnórsson, 1987; Markússon and Stefánsson, 2011). For example, reservoir waters sampled in boreholes (Arnórsson et al., 1975) show a range of salinities, and a number of them are colder (Fig. 3a) and more C-rich (Fig. 4a), implicating that mixing with shallower, meteoric fluids is a recurrent process at depth. This process is illustrated (in Figs. 3a and $4 a$ ) by families of mixing lines connecting our initial solution (our meteoric end-member) with model aqueous solutions from high-T runs. Reservoir waters find no surface expression at Krýsuvík (contrary to other hydrothermal systems, where neutral $\mathrm{Na}-\mathrm{Cl}$ thermal springs are commonly encountered; Giggenbach, 1988). Instead, the majority of the surface waters at Krýsuvík are hot, acidic mud pools and springs with $\mathrm{Ca}-\mathrm{Mg}-\mathrm{SO}_{4}$-dominated compositions (Markússon and Stefánsson, 2011) (see Fig. 4). These acidic fluids are thought to result from shallow-level condensation of rising hydrothermal steams (Arnórsson, 1987; Arnórsson et al., 1975; Markússon and Stefánsson, 2011). We used EQ3/6 to model dissolution of a typical Krýsuvík hydrothermal steam ( 99.44 vol.\% $\mathrm{H}_{2} \mathrm{O}, 0.49$ vol.\% $\mathrm{CO}_{2}, 0.11$ vol.\% $\mathrm{H}_{2} \mathrm{~S}$ ) into our initial solution (we assume the process occurs at 1.013 bar, $53-100{ }^{\circ} \mathrm{C}$ and $\log \mathrm{fO}_{2}=0.8$ ), and obtain model solutions ("model steam-heated waters" in Fig. 4a) that agree well with measured composition. This match again confirms utility and versatility of EQ3/6 in simulation hydrothermal processes.

\section{Conclusions}

We have here demonstrated that EQ3/6-based reaction path modeling is a powerful tool to quantitatively explore mechanisms and pathways influencing volcanic fluids. Our numerical simulations of gas-water-rock reactions, conducted at shallow-to-deep hydrothermal conditions, generate model results that are in good quantitative agreement with measured fluid (surface and reservoir) compositions in Iceland. We conclude that scrubbing is widespread, and that the magmatic gas phase, as it travels to the surface, is variably affected by scrubbing, in either hydrothermal (high-T) or groundwater (low-T) environment, to assume the compositional features seen exhibited by hydrothermal reservoir fluids and/or surface discharges.

At hydrothermal reservoir conditions (temperatures of $200-250{ }^{\circ} \mathrm{C}$ ), our gas-water-rock reaction path models demonstrate that magmatic volatiles are variably (either completely or partially) scrubbed into reservoir waters. These simulations yield model aqueous solutions which dissolved $\mathrm{CO}_{2}$ and $\mathrm{H}_{2} \mathrm{~S}$ contents are well consistent with those observed in natural samples (reservoir fluids sampled in boreholes). Our simulated aqueous solutions also have major element compositions (of $\mathrm{Na}-\mathrm{K}-\mathrm{Cl}$ type) that reflect well the hydrothermal maturation path, from "immature", acidic Mg-rich waters, to mature neutral hydrothermal reservoir brines. We also show that single-step boiling of our $200-250{ }^{\circ} \mathrm{C}$ aqueous solutions, down to $100^{\circ} \mathrm{C}$, produces modeled steam compositions that match well the observed compositional range of natural hydrothermal steam discharges, including those of Krýsuvík. We also model condensation of this hydrothermal steam into a shallow meteoric aquifer, and obtain model solutions that are compositionally similar to the steam-heated groundwaters found in the field at Krýsuvík (Markússon and Stefánsson, 2011).

Our low-T model runs are initialized in the attempt to simulate interaction of magmatic gases with a shallow hydrologic system, as possibly today occurring at Hekla volcano. We find that our model runs generate model gases with $\mathrm{CO}_{2}$-dominated compositions, matching well those of the Icelandic cold gas emissions from Hekla, Grímsvötn and Eldfell.

We finally conclude that our EQ3/6-based models, once properly initialized, can open the way to investigating magmatic gas scrubbing in a variety of hydrothermal and volcanic contexts worldwide.

\section{Acknowledgements}

The research leading to these results has received funding from the European Community's Seventh Framework Program under Grant Agreements No. 308377 (Project FUTUREVOLC) and ERC grant agreement no. 305377 (Project BRIDGE). Dr. G. Chiodini and an anonymous Reviewer are acknowledged for their insightful comments on the manuscript.

\section{Appendix A. Reaction path models and their input parameters}

Reaction path modelling is initialized via EQ3NR, the EQ3/6 module used to calculate speciation of the initial aqueous solution (see below and Table 1). This initial aqueous solution is then transferred to the EQ6 module to initiate the reaction path runs. The EQ6 input file also includes the compositions of gas and/or solid phases interacting with the initial aqueous solution, listed as reactant species (Table 1). The initial amounts (moles) of each different reactant $\left(n_{g}\right.$ and $n_{s}$; Table 2 ) is also specified in the input file. The mass of solid reactants $\left(n_{s}\right.$ in Table 2$)$ is calculated from the total volume of solids in contact with $1 \mathrm{~kg}$ of initial aqueous solution.

The EQ3/6 model simulations were initialised by fixing a priori a suite of input parameters:

(i) Initial aqueous solution: this is the starting aqueous solution for the first run (e.g., A_1, B_1, etc.) of each run type (see Fig. 2). We adopted as initial aqueous solution a low-salinity (Total Dissolved Solids, TDS $=300 \mathrm{mg} / \mathrm{l})$ cold $\left(\mathrm{T}=4.1^{\circ} \mathrm{C}\right.$ ) water (Holm et al., 2010), which we consider as representative for the meteoric recharge of Icelandic aquifers (Table 1). In later runs (A_2, A_3, B_2, B_3...), the starting aqueous solution is the degassed aqueous solution (cfr. Section 2.3) formed in the previous run (A_1, A_2, B_1, B_2...) (see Fig. 2 and Section 4). One kilogram of either the initial or starting aqueous solution was allowed to react with a set of reactants (gas and solids);

(ii) Initial gas: the initial gas is, by definition, the high temperature magmatic gas phase that reacts with (and partially dissolves into) each starting aqueous solution. There are unfortunately only a few compositional reports for high-temperature magmatic gases in Iceland, implying that the deep gas supply sustaining the activity of geothermal systems in Iceland is currently poorly determined (cfr. Section 3). We here take the gas measured by

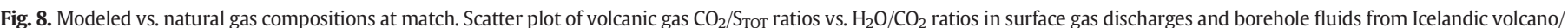

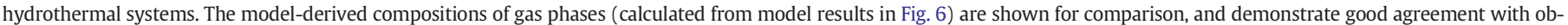

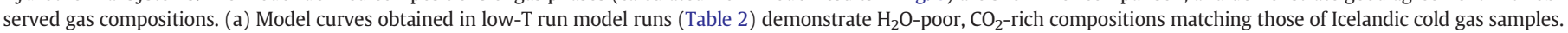

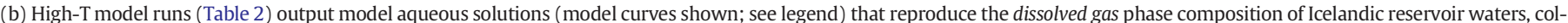

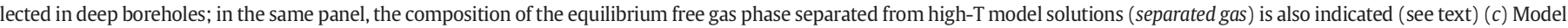

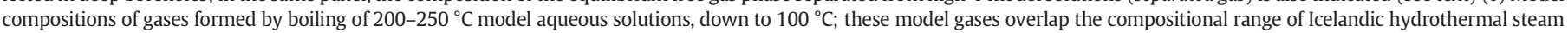
samples (shown in (a)), and fit well the compositions of fumarolic steam discharges at Krýsuvík. 
Table A.1

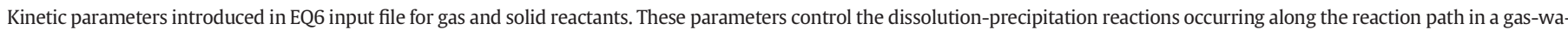
ter-rock system. See Appendix A for details.

\begin{tabular}{|c|c|c|c|c|c|c|}
\hline Reactants & $\begin{array}{l}\text { Entered in EQ6 } \\
\text { input file as: }\end{array}$ & $\begin{array}{l}\text { Dissolution } \\
\text { rate }\end{array}$ & $\begin{array}{l}\text { Dissolution rate constant }(k \text {; } \\
\left.\mathrm{mol} \cdot \mathrm{cm}^{-2} \cdot \mathrm{s}^{-1}\right)\end{array}$ & $\begin{array}{l}\text { Apparent activation energy } \\
\left(E_{a} ; \mathrm{kcal} \cdot \mathrm{mol}^{-1}\right)\end{array}$ & $\begin{array}{l}\text { BET specific surface area } \\
\left(A_{B E T} ; \mathrm{cm}^{2} / \mathrm{g}\right)\end{array}$ & $\begin{array}{l}\text { Total surface area } \\
\left(s ; \mathrm{cm}^{2}\right)\end{array}$ \\
\hline Initial gas & Gas reactant & relative rate $1-100^{(1)}$ & & & & \\
\hline Hyd-Hekla-glass & Solid reactant & TST rate law & $8.56 \cdot 10^{-11}$ (at $25^{\circ} \mathrm{C}$ ) & 6.09 (at $25^{\circ} \mathrm{C}$ ) & 1200 & $7.81 \cdot 10^{6}$ \\
\hline Hekla-glass-cations & Special reactant & relative rate $1^{(2)}$ & & - & & \\
\hline Hyd-Krýsuvík-glass & Solid reactant & TST rate law & $8.56 \cdot 10^{-11}$ (at $25^{\circ} \mathrm{C}$ ) & 6.09 (at $25^{\circ} \mathrm{C}$ ) & 1400 & $3.44 \cdot 10^{7}$ \\
\hline Krýsuvík-glass-cations & Special reactant & relative rate $1^{(3)}$ & & - & & \\
\hline
\end{tabular}

${ }^{(1)}$ dissolution rate relative to Hyd- Hekla or Krýsuvík-glass rate; ${ }^{(2)}$ and ${ }^{(3)}$ are dissolution rates relative to Hyd-Hekla-glass rate and Hyd-Krýsuvík-glass rate, respectively.

Burton et al. (2010) during the March 2010 Fimmvörduháls fissure eruption of the Eyjafjallajökull volcano as a proxy for high-T magmatic gas supply in Iceland. This Fimmvörduháls gas was thus selected as initial gas for our models (Tables 1 and 2). We are well aware, however, that the feeding magmatic gas in Iceland can be spatially and temporally variable, and that a more hydrous magmatic gas was for example vented during the Surtsey eruption in 1963 and, more recently, during the 2014-2015 Holuhraun eruption of the Bárðarbunga volcano (Gíslason et al., 2015; Pfeffer et al., 2015). Tests made using Surtsey or Holuhraun gas as initial gas in our model runs outputted model gas trends qualitatively similar (only slightly more water-rich) than those presented here. The amount ( $n_{g, \text { ТОT }}$ and $n_{g, r u n}$ moles) of Fimmvörduháls initial gas added to the starting aqueous solution in each run type, and per run, is reported in Table 2.

(iii) Solid reactants: two different aquifer rocks were considered in our modelling as solid reactants (Table 1 ). A basaltic andesitic glass ( $\mathrm{SiAl}_{0.31} \mathrm{Fe}_{0.17} \mathrm{Mg}_{0.08} \mathrm{Ca}_{0.13} \mathrm{Na}_{0.14} \mathrm{~K}_{0.03} \mathrm{O}_{2.96}$; Wolff-Boenisch et al. 2004), from the 2000 eruption of Hekla (Moune et al. 2006; 2007), was used in the low-T model runs (Tables 1 and 2); since no thermodynamic data are available for the aquifer rocks at Krýsuvík geothermal system, we selected a basaltic glass from Krafla volcano $\left(\mathrm{SiAl}_{0.32} \mathrm{Fe}_{0.24} \mathrm{Mg}_{0.17} \mathrm{Ca}_{0.22} \mathrm{Na}_{0.09} \mathrm{~K}_{0.01} \mathrm{O}_{3.18}\right.$; WolffBoenisch et al. 2004), similar in composition to Krýsuvík basalts (Markússon and Stefánsson, 2011; Peate et al., 2009), for our high-T model runs (Tables 1 and 2). Following Oelkers and Gíslason (2001), we assume that only a hydrated surface layer (enriched in $\mathrm{Si}$, $\mathrm{Al}$ and $\mathrm{OH}$ groups) of the basaltic glass equilibrates with leaching solutions. We therefore initialized our modelling using the following solid reactants: "Hyd-Hekla-glass" $\left(\mathrm{SiAl}_{0.31} \mathrm{O}_{2}(\mathrm{OH})_{0.93}\right)$ and "Hyd-Krýsuvík-glass" $\left(\mathrm{SiAl}_{0.32} \mathrm{O}_{2}(\mathrm{OH})_{0.96}\right)$ (Tables 1 and 2), which correspond to hydrated volcanic glasses of, respectively, a basaltic andesite from Hekla and a basalt from Krafla (Wolff-Boenisch et al., 2004). These reactants dissolve according to the following reactions (Eqs. (A1)-(A2)):

$$
\begin{aligned}
& \text { Hyd-Hekla-glass }+0.93 \mathrm{H}^{+}=\mathrm{SiO}_{2}+0.93 \mathrm{H}_{2} \mathrm{O}+0.31 \mathrm{Al}^{3+} \\
& \text { Hyd-Krýsuvík-glass }+0.96 \mathrm{H}^{+}=\mathrm{SiO}_{2}+0.96 \mathrm{H}_{2} \mathrm{O}+0.32 \mathrm{Al}^{3+}
\end{aligned}
$$

The total amounts of solid reactant interacting with $1 \mathrm{~kg}$ of starting aqueous solution, listed in the EQ6 input file, were computed using effective inter-granular porosities of 0.3 (Hekla) and 0.11 (Krýsuvík; Arnórsson et al., 1975). We assume that pore spaces of the solid reactant are water-saturated, and we use densities of $2.79 \mathrm{~g} / \mathrm{cm}^{3}$ and $3.04 \mathrm{~g} / \mathrm{cm}^{3}$ for respectively Hyd-Hekla-glass and Hyd-Krýsuvík-glass (Wolff-Boenisch et al., 2004). A total of $77.26 \mathrm{~mol}$ of Hyd-Hekla-glass and $289.23 \mathrm{~mol}$ of Hyd-Krýsuvíkglass were used respectively in low-T and in high-T model runs (Table 2).

In order to include the rock-forming metals not included in the hydrated glass compositions (see Eqs. (A.1)-(A.2) and Table 1), we used two different special reactants (Wolery and Daveler, 1992), here referred as Hekla-glass-cations and Krýsuvík-glass-cations (Table 1). Each special reactant is entered in the EQ6 input file in same amount as the corresponding hydrated glass ( $77.26 \mathrm{~mol}$ of Hekla-glass-cations and $289.23 \mathrm{~mol}$ of Krýsuvík-glass-cations; see Table 2), and its composition is specified as moles of metals per mole of special reactant (see Table 1 ).

(iv) Kinetic data: In order to allow our reaction path modeling to run in time mode, the kinetic parameters for each reactant (gas and solid) must be fixed in the input file. Kinetic parameters of dissolution-precipitation reactions are fixed by a specific rate law in the EQ6 input file. For irreversible reactions involving solid phases, the Transition State Theory (TST) rate law (Wolery and Daveler, 1992), which is a function of aqueous solution chemistry (Table A.1), was used. Consequently, the input file was implemented with the dissolution rate constant $\left(k ; \mathrm{mol} \cdot \mathrm{cm}^{-2} \cdot \mathrm{s}^{-1}\right)$, the apparent activation energy $\left(E_{a} ; \mathrm{kcal} \cdot \mathrm{mol}^{-1}\right)$ (Gíslason and Oelkers, 2003), and the total surface area $\left(s ; \mathrm{cm}^{2}\right.$ ) (derived from measured BET specific surface area; Wolff-Boenisch et al., 2004) for both Hyd-Hekla-glass and Hyd-Krýsuvík-glass (see Table A.1). Special reactants were set to dissolve at the same rate as the corresponding solid reactant (relative rate equal to 1 ; cfr. Section 2.1 ) for both Hekla-glass-cations and Krýsuvík-glass-cations (Table A.1).

The initial gas dissolves into the aqueous solution at a rate that is unknown (as a function of parameters such as the gas flux, or the gas/water ratio etc.), but in any case faster than that of basaltic glass (see below); in each simulation run, we therefore assumed a relative dissolution rate of the initial gas as being $n$ times that of the solid reactant. A range of $n$ values was explored ("initial gas relative dissolution rate" in Table 2).

Since rate laws are entered in the EQ6 input file, the reaction path calculations have a defined time frame (simulations in time mode).

(v) run pressure: in each single run (Table 2), pressure was taken as either 1.013 bar (run types A-D) or as the water saturation pressure at run temperature (run types $\mathrm{E}-\mathrm{H}$ ).

(vi) run temperature: in the low-T runs (run types A-D), we calculated (and entered in the input file) the temperature $T_{\text {run } \_n}$ of each single run (e.g. run_1 in Fig. 2; A_1 run in Table 2) assuming enthalpy is conserved during mixing between the starting aqueous solution and the initial gas. We express the enthalpy balance as (modified from Spycher and Reed, 1988):

$H_{S, T_{\text {run } \_n}}=H_{w, T_{w}} \cdot \frac{1000}{M W_{w}}+n_{g, r u n_{-} n} \sum_{j} H_{j, T_{j}} \cdot X_{j}$

where $H_{w, T w}$ and 1000/MW $\mathrm{MW}_{\mathrm{w}}$ are respectively enthalpy $(\mathrm{J} / \mathrm{mol})$ and amount ( $\mathrm{mol}$ ) of starting aqueous solution (here assimilated to pure water) at its temperature $\left(T_{w},{ }^{\circ} \mathrm{C}\right) ; n_{g, r u n \_n}(\mathrm{~mol})$ stands for the amount of initial gas added in the considered run $(n)$, and $H_{j, T j}$ and $X_{j}$ are, respectively, enthalpy $(\mathrm{J} / \mathrm{mol})$ and molar fraction of the $\mathrm{j}$-th gas species in gas phase, at initial gas temperature $\left(T_{j},{ }^{\circ} \mathrm{C}\right)$. 
From enthalpy $H_{s, T r u n \_n}$, run temperature $\left(T_{r u n \_n}\right)$ was calculated as:

$$
\begin{aligned}
& T_{\text {run } \_n}=-3 \cdot 10^{-17}\left(H_{s, T r u n \_n}\right)^{4}-1 \cdot 10^{-12}\left(H_{\text {Ts,Trun } \_n}\right)^{3} \\
& +1 \cdot 10^{-8}\left(H_{T s, T r u n \_n}\right)^{2}+0.0132 H_{T s, T r u n \_n}+0.01
\end{aligned}
$$

This relation is derived by combining the Denbigh's (1971) enthalpy equation with the heat capacity power expression, proposed by Chase (1998).

$$
\begin{aligned}
H_{\text {Trun_n } n}= & H_{T_{\text {triple }}} \\
& +\left[a\left(T_{\text {run_n }}-T_{T_{\text {triple }}}\right)+\frac{b}{2}\left(T^{2}-T_{T_{\text {triple }}}{ }^{2}\right)+\frac{c}{3}\left(T^{3}-T_{T_{\text {triple }}}{ }^{3}\right)+\ldots\right]
\end{aligned}
$$

This temperature is used (and kept constant) during each single run simulation. As shown in Fig. A.1, the temperature of the degassed aqueous solutions (Fig. 2) (corresponding to model run temperature) increases proportionally to the amount of initial gas added in the model run (Table 2). The low-T run types (AD) give rise in Fig. A.1 to four overlapping model trends, that demonstrate that a total of $6.6 \mathrm{~mol}$ of initial gas are required to raise the model run temperature, from $4.1{ }^{\circ} \mathrm{C}$ (the temperature of the initial aqueous solution; blue square in Fig. A.1) to $106^{\circ} \mathrm{C}$. The high-T model runs (E-H) were operated at constant temperatures of either 200 or $250{ }^{\circ} \mathrm{C}$ (Table 2). These temperatures reflect the range of reservoir temperatures estimated/measured at Krýsuvík (Arnórsson, 1987; Arnórsson and Gunnlaugsson, 1985; Arnórsson et al., 1975). The enthalpy balance (Eq. (A.3)) is not used in high-T runs, because we assume conductive heating of recharge waters as they infiltrate through hot rocks formations of the hydrothermal system.

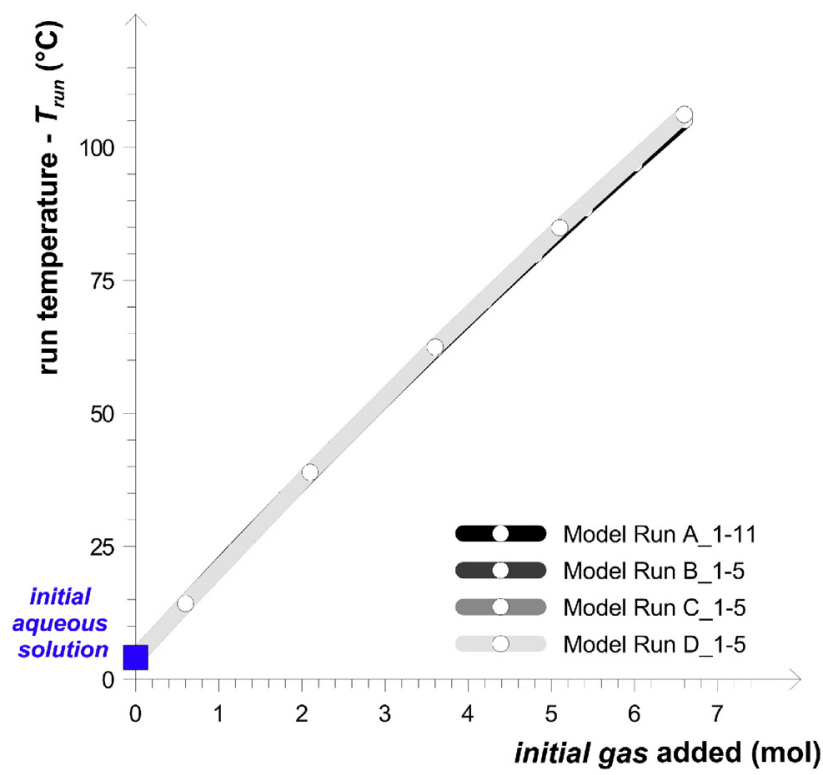

Fig. A.1. Model run temperature $\left(\mathrm{T}_{\text {run }}\right)$ vs. amount of initial gas (mol) added per run. In low-T model runs, the temperature of each single run $\left(T_{\text {run_n }}\right)$ (see also Fig. 2 ) is calculated by enthalpy balance, according to Eq. (A.3). $\mathrm{T}_{\text {run }}$ increases proportionally to the moles of initial (magmatic) gas added to the starting aqueous solution (Table 2). Results for each run (e.g., A_1, A_2...; Table 2) and model run types (A-D; Table 2) are plotted (see legend), and describe four overlapping model trends. $6.6 \mathrm{~mol}$ of initial gas are required to raise the model run temperature $\left(\mathrm{T}_{\mathrm{run}}\right)$, from $4.1{ }^{\circ} \mathrm{C}$ (the temperature of the initial aqueous solution; blue square) to $106{ }^{\circ} \mathrm{C}$. (vii) redox conditions: redox conditions in hydrothermal reservoirs are known to be controlled by reactions involving redox couples (Chiodini and Marini, 1998). In our high-T model runs (Table 2), we therefore fixed the oxygen fugacity $\left(\operatorname{as~} \log f_{\mathrm{O} 2}\right)$ using the empirical relation proposed by D'Amore and Panichi (1980). This redox buffering control is hardly extendable to shallow groundwater systems, and oxygen fugacity was not externally fixed in our low-T model runs simulations.

\section{Appendix B. Database implementation}

EQ6 uses thermodynamic data from the data0 database. Implementation of the original data0.com.R10 (Wolery, 1992a,b) database was required, in order to include the new gas and solid reactants used in our modeling. Element compositions, dissolution reactions and equilibrium constants (as $\log \mathrm{K}$ ) at different $\mathrm{T}$ (from 0 to $300{ }^{\circ} \mathrm{C}$ ) were implemented for both initial gas and solid reactants (Tables 1 and 2). Equilibrium constants $(\log \mathrm{K})$ of the initial gas dissolution reaction were derived from dissociation of pure $\mathrm{H}_{2} \mathrm{O}_{(\mathrm{g})}, \mathrm{CO}_{2(\mathrm{~g})}, \mathrm{SO}_{2(\mathrm{~g})}$ and $\mathrm{HCl}_{(\mathrm{g})}$. For each solid reactant (Hyd-Hekla-glass and Hyd-Krýsuvík-glass; Table 1), we simply derived the equilibrium constants $(\log K)$ consistent with the dissolution reactions reported in Eqs. (A.1)-(A.2), by summing (stoichiometrically weighted sum) the log K of amorphous silica and gibbsite hydrolysis reactions (Oelkers and Gíslason, 2001).

\section{References}

Aiuppa, A., Federico, C., Giudice, G., Gurrieri, S., 2005. Chemical mapping of a fumarolic field: La Fossa crater, Vulcano island (Aeolian islands, Italy). Geophys. Res. Lett. 32. http://dx.doi.org/10.1029/2005GL023207.

Aiuppa, A., Giudice, G., Liuzzo, M., Tamburello, G., Allard, P., Calabrese, S., Chaplygin, I., McGonigle, A.J.S., Taran, Y., 2012. First volatile inventory for Gorely volcano, Kamchatka. Geophys. Res. Lett. 39.

Aiuppa, A., Tamburello, G., Di Napoli, R., Cardellini, C., Chiodini, G., Giudice, G., Grassa, F. Pedone, M., 2013. First observations of the fumarolic gas output from a restless caldera: implications for the current period of unrest (2005-2013) at Campi Flegrei. Geochem. Geophys. Geosyst. 14. http://dx.doi.org/10.1002/ggge.20261.

Aiuppa, A., Robidoux, P., Tamburello, G., Condec, V., Galle, B., Avard, G., Bagnato, E., De Moor, J.M., Martínez, M., Muñóz, A., 2014. Gas measurements from the Costa RicaNicaragua volcanic segment suggest possible along-arc variations in volcanic gas chemistry. Earth Planet Sci. Lett 407, 134-147.

Ármannsson, H., Gíslason, G., Hauksson, T., 1982. Magmatic gases in well fluids aid the mapping of flow pattern in a geothermal system. Geochim. Cosmochim. Acta 46, 167-177.

Arnórsson, S., 1983. Chemical equilibria in Icelandic geothermal systems-implications for chemical geothermometry investigations. Geothermics 12, 119-128.

Arnórsson, S., 1985. The use of mixing models and chemical geothermometers for estimating underground temperatures in geothermal systems. J. Volcanol. Geotherm. Res. 23, 299-335.

Arnórsson, S., 1986. Chemistry of gases associated with geothermal activity and volcanism in Iceland: a review. J. Geophys. Res. 91, 12261-12268.

Arnórsson, S., 1987. Gas chemistry of the Krýsuvík geothermal field, Iceland, with special reference to evaluation of steam condensation in upflow zones. Jökull 37, 30-47.

Arnórsson, S., 1995. Geothermal systems in Iceland: structure and conceptual models - I. High-Temperature Areas. Geothermics 24, 561-602.

Arnórsson, S., Barnes, I., 1983. The nature of carbon dioxide waters in Snaefellsnes, western Iceland. Geothermics 12, 171-176.

Arnórsson, S., Gunnlaugsson, E., 1985. New gas geothermometers for geothermal exploration-calibration and application. Geochim. Cosmochim. Acta 49, 1307-1325.

Arnórsson, S., Gunnlaugsson, E., Svavarsson, H., 1983. The chemistry of geothermal waters in Iceland, II. Mineral equilibria and independent variables controlling water compositions. Geochim. Cosmochim. Acta 47, 547-566.

Arnórsson, S., Guðmundsson, G., Sigurmundsson, S.G., Björnsson, A., Gunnlaugsson, E., Gíslason, G., Jónsson, J., Einarsson, P., Björnsson, S., 1975. Systematic exploration of the Krísuvík high-temperature area, Reykjanes-Peninsula, Iceland. Report, National Energy Authority, Reykjavik, Iceland. OS/JHD 7554127 pp.).

Arnórsson, S., Stefánsson, A., Bjarnason, J.Ö., 2007. Fluid-fluid interactions in geothermal systems. Rev. Mineral. Geochem. 65, 259-312.

Barry, P.H., Hilton, D.R., Füri, E., Halldórsson, S.A., Grönvold, K., 2014. Carbon isotope and abundance systematics of Icelandic geothermal gases, fluids and subglacial basalts with implications for mantle plume-related $\mathrm{CO}_{2}$ fluxes. Geochim. Cosmochim. Acta 134, 74-99.

Barth, T.F.W., 1950. Volcanic Geology, hot springs and Geysers of Iceland. Carnegie Inst. of Wash., Washington, D.C., p. 174

Bjarnason, J.O., 2000. A note on the chemical composition of geothermal steam from well KR-9 in Krýsuvík, southwestern Iceland. Report JÖB-2000/01, March, 2000. 
Burton, M.R., Salerno, G.G., La Spina, A., Stefansson, A., Kaasalainen, H., 2010. Measurements of volcanic gas emissions during the first phase of 2010 eruptive activity of eyjafallajokull. Presented at the AGU Fall Meeting, Abstract V41E -2310. AGU, San Francisco, California.

Burton, M., La Spina, A., Ilyinskaya, E., Salerno, G., 2014. Open Path FTIR and $\mathrm{SO}_{2}$ Camera Measurements of the Holuhraun Eruption Iceland 2014. Presented at the 12th Field Workshop on Volcanic Gases. CCVG, Atacama, Chile.

Chase, M.W., 1998. NISTJANAF Thermochemical Tables. 4th ed.J. Phys. Chem. Ref. Data Monograph, 9.

Chiodini, G., Marini, L., 1998. Hydrothermal gas equilibria: the $\mathrm{H}_{2} \mathrm{O}-\mathrm{H}_{2}-\mathrm{CO}_{2}-\mathrm{CO}-\mathrm{CH}_{4}$ system. Geochim. Cosmochim. Acta 62, 2673-2687.

D'Amore, F., Panichi, C., 1980. Evaluation of deep temperature of hydrothermal systems by a new gas-geothermometer. Geochim. Cosmochim. Acta 44, 549-556.

Daveler, S.A., Wolery, T.J., 1992. EQPT, A Data File Preprocessor for the EQ3/6 Software Package: User's Guide and Related Documentation (Version 7.0). Report UCRL-MA110662 PT II. Lawrence Livermore National Laboratory, Livermore, California.

Denbigh, K., 1971. The Principles of Chemical Equilibrium. 3rd ed. Cambridge University Press, Cambridge.

Di Napoli, R., Aiuppa, A., Allard, P., 2013. First multi-GAS based characterization of the boiling lake volcanic gas (Dominica, Lesser Antilles). Ann. Geophys. 56 (5), S0559. http://dx.doi.org/10.4401/ag-6277.

Doukas, M.P., Gerlach, T.M., 1995. Sulfur dioxide scrubbing during the 1992 eruptions of crater peak, Mount Spurr volcano, Alaska. U.S. Geol. Surv. Bull. B-2139, 47-57.

Flaathen, T., Gíslason, S.R., 2007. The effect of volcanic eruptions on the chemistry of surface waters: the 1991 and 2000 eruptions of Mt. Hekla, Iceland. J. Volcanol. Geotherm. Res. 164, 293-316.

Flaathen, T., Gíslason, S.R., Oelkers, E., Sveinbjornsdottir, A., 2009. Chemical evolution of the Mt. Hekla, Iceland, groundwaters: a natural analogue for $\mathrm{CO}_{2}$ sequestration in basaltic rocks. Appl. Geochem. 24, 463-474.

Fournier, R.O., 1989. Geochemistry and dynamics of the Yellowstone national park hydrothermal system. Annu. Rev. Earth Planet. Sci. 17, 13-53.

Garcia, S., Arnaud, N., Angelier, J., Bergerat, F., Homberg, C., 2003. Rift jump processes in northern Iceland since $10 \mathrm{Ma}$ from ${ }^{40} \mathrm{Ar} /{ }^{39} \mathrm{Ar}$ geochronology. Earth Planet. Sci. Lett. 214, 529-544.

Gerlach, T.M., McGee, K.A., Doukas, M.P., 2008. Emission rates of $\mathrm{CO}_{2}, \mathrm{SO}_{2}$, and $\mathrm{H}_{2} \mathrm{~S}$, scrubbing, and pre-eruption excess volatiles at Mount St. Helens, 2004-2005. In: Sherrod, D.R., Scott, W.E., Stauffer, P.H. (Eds.), a volcano rekindled: the renewed eruption of Mount St. Helens, 2004-2006. US Geol. Surv. Prof. Pap. 1750, pp. 554-571.

Giggenbach, W.F., 1980. Geothermal gas equilibria. Geochim. Cosmochim. Acta 44, 2021-2032.

Giggenbach, W.F., 1981. Geothermal mineral equilibria. Geochim. Cosmochim. Acta 45, 393-410.

Giggenbach, W.F., 1984. Mass transfer in hydrothermal alterations systems. Geochim. Cosmochim. Acta 48, 2693-2711.

Giggenbach, W.F., 1987. Redox processes governing the chemistry of fumarolic gas discharges from White Island, New Zeland. Appl. Geochem. 2, 143-161.

Giggenbach, W.F., 1988. Geothermal solute equilibria. Derivation of Na-K-Mg-Ca geoindicators. Geochim. Cosmochim. Acta 52, 2749-2765.

Giggenbach, W.F., 1993. Redox control of gas compositions in Philippine volcanichydrothermal systems. Geothermics 22, 575-587.

Gíslason, S.R., Andrésdóttir, A., Sveinbjörnsdóttir, Á., Oskarsson, N., Thordarson, T., Torssander, P., Novâk, M., Zâk, K., 1992. Local effects of volcanoes on the hydrosphere: example from Hekla, southern Iceland. Water-rock Interaction: Rotterdam, Balkema. 1, pp. 477-481.

Gíslason, S.R., Oelkers, E.H., 2003. The mechanism, rates, and consequences of basaltic glass dissolution: II. An experimental study of the dissolution rates of basaltic glass as a function of $\mathrm{pH}$ at temperatures from $6{ }^{\circ} \mathrm{C}$ to $150{ }^{\circ} \mathrm{C}$. Geochim. Cosmochim. Acta 67, 3817-3832.

Gíslason, S.R., Stefánsdóttir, G., Pfeffer, M.A., Barsotti, S., Jóhannsson, T., Galeczka, I., Bali, E., Sigmarsson, O., Stefánsson, A., Keller, N.S., Sigurdsson, Á., Bergsson, B., Galle, B., Jacobo, V.C., Arellano, S., Aiuppa, A., Jónasdóttir, E.B., Eiríksdóttir, E.S., Jakobsson, S., Guðfinnsson, G.H., Halldórsson, S.A., Gunnarsson, H., Haddadi, B., Jónsdóttir, I., Thordarson1, M., Riishuus, T., Högnadóttir, T., Dürig, T., Pedersen, G.B.M., Höskuldsson, Á., Gudmundsson, M.T., 2015. Environmental pressure from the 2014-15 eruption of Bárðarbunga volcano, Iceland. Geochem. Perspect. lett. http:// dx.doi.org/10.7185/geochemlet.1509.

Guðjónsdóttir, S.R., 2014. Gas Emissions from the Krýsuvík High-Temperature Geothermal System, Iceland (Master's thesis) Faculty of Earth Sciences. University of Iceland (72 pp.).

Guðmundsson, G., Arnórsson, S., Sigurmundsson, S.G., Björnsson, A., Gunnlaugsson, E., Gíslason, G., Jónsson, J., Einarsson, P., Björnsson, S., 1975. The Krýsuvík area, report on geothermal observations (in Icelandic). Report OSJHD 7554, November 1975 (71 pp.).

Gysi, A.P., Stefánsson, A., 2011. $\mathrm{CO}_{2}$-water-basalt interaction. Numerical simulation of low temperature $\mathrm{CO}_{2}$ sequestration into basalts. Geochim. Cosmochim. Acta 75, 4728-4751.

Gysi, A.P., Stefánsson, A., 2012. Experiments and geochemical modeling of $\mathrm{CO}_{2}$ sequestration during hydrothermal basalt alteration. Chem. Geol. 306-307, 10-28.

Helgeson, H.C., 1968. Evaluation of irreversible reactions in geochemical processes involving minerals and aqueous solutions: I. Thermodynamic relations. Geochim. Cosmochim. Acta 32, 853-877.

Helgeson, H.C., Garrels, R.M., Mackenzie, F.T., 1969. Evaluation of irreversible reactions in geochemical processes involving minerals aqueous solutions: II. Applications. Geochim. Cosmochim. Acta 33, 455-481.

Henley, R.W., Truesdell, A.H., Barton Jr., P.B., Whitney, J.A., 1984. Fluid-mineral equilibria in hydrothermal systems. Rev. Econ. Geol. 1.
Holm, N.G., Gíslason, S.R., Sturkell, E., Torssander, P., 2010. Hekla cold springs (Iceland): groundwater mixing with magmatic gases. Isot. Environ. Health Stud. 46, 180-189.

Höskuldsson, A., Hey, R., Kjartansson, E., Gudmundsson, G.B., 2007. The Reykjanes Ridge between $63^{\circ} 10^{\prime} \mathrm{N}$ and Iceland. J. Geodyn. 43, 73-86.

Kaasalainen, H., Stefánsson, A., 2012. The chemistry of trace elements in surface geothermal waters and steam, Iceland. Chem. Geol. 330-331, 60-85.

Kurz, M.D., Meyer, P.S., Sigurdsson, H., 1985. Helium isotope systematics within the neovolcanic zones of Iceland. Earth Planet. Sci. Lett. 74, 29l-2305.

Ilyinskaya, E., Aiuppa, A., Bergsson, B., Di Napoli, R., Fridriksson, T., Óladóttir, A.A. Óskarsson, F., Grassa, F., Pfeffer, M., Lechner, K., 2015. Degassing regime of Hekla volcano 2012-2013. Geochim. Cosmochim. Acta 159, 80-99.

Larsen, G., Dugmore, A., Newton, A., 1999. Geochemistry of historical-age silicic tephras in Iceland. The Holocene 9, 463-471.

Macpherson, C.G., Hilton, D.R., Day, J.M.D., Lowry, D., Grönvold, K., 2005. High ${ }^{3} \mathrm{He} /{ }^{4} \mathrm{He}$ depleted mantle and low- $\delta^{18} \mathrm{O}$, recycled oceanic lithosphere in the source of central Iceland magmatism. Earth Planet. Sci. Lett. 223, 411-427.

Markússon, S., Stefánsson, A., 2011. Geothermal surface alteration of basalts, Krýsuvík Iceland-aleteration mineralogy, water chemistry and the effects of acid supply on the alteration process. J. Volcanol. Geotherm. Res. 206, 46-59.

Marini, L., Gambardella, B., 2005. Geochemical modeling of magmatic gas scrubbing. Ann. Geophys. 48, 739-753.

Marty, B., Gunnlaugsson, E., Jambon, A., Oskarsson, N., Ozima, M., Pineau, F., Torssander, P. 1991. Gas geochemistry of geothermal fluids, the Hengill area, southwest rift zone of Iceland. Chem. Geol. 91, 207-225.

Moune, S., Gauthier, P.J., Gíslason, S.R., Sigmarsson, O., 2006. Trace element degassing and enrichment in the eruptive plume of the 2000 eruption of Hekla volcano, Iceland. Geochim. Cosmochim. Acta 70, 461-479.

Moune, S., Sigmarsson, O., Thordarson, T., Gauthier, P.J., 2007. Recent volatile evolution in the magmatic system of Hekla volcano, Iceland. Earth Planet. Sci. Lett. 255, 373-389.

Nordstrom, K.D., McCleskey, B.R., Ball, J.W., 2009. Sulfur geochemistry of hydrothermal waters in Yellowstone national park: IV acid-sulfate waters. Appl. Geochem. 24, 191-207.

Oelkers, E.H., Gíslason, S.R., 2001. The mechanism, rates, and consequences of basaltic glass dissolution: I. An experimental study of the dissolution rates of basaltic glass as a function of aqueous $\mathrm{Al}, \mathrm{Si}$, and oxalic acid concentration at $25^{\circ} \mathrm{C}$ and $\mathrm{pH}=3$ and 11. Geochim. Cosmochim.Acta 65, 3671-3681.

Oskarsson, N., 1984. Monitoring of fumarole discharge during the 1975-1982 rifting in krafla volcanic center, north Iceland. J. Volcanol. Geotherm. Res. 22, 97-121.

Peate, D.W., Baker, J.A., Jakobsson, S.P., Waight, T.E., Kent, A.J.R., Grassineau, N.V., Skovgaard, A.C., 2009. Historic magmatism on the Reykjanes peninsula, Iceland: a snap shot of melt generation at a ridge segment. Contrib. Mineral. Petrol. 157, 359-382.

Pfeffer, M.A., Stefánsdóttir, G., Bergsson, B., Barsotti, S., Galle, B., Conde, V., Donovan, A. Aiuppa, A., Burton, M., Keller, N.S., Askew, R.A., Ilyinskaya, E., La Spina, A., Sigurðardóttir, G.M., Jónasdóttir, E.B., Snorrason, A., Stefánsson, A., Tsanev, V., 2015. Ground-based measurements of the emission rate and composition of gases from the Holuhraun eruption. Presented at the EGU Fall Meeting, Abstract. Vienna, Austria, pp. 2015-7373.

Polak, B.G., Kononovi, I., Tolstikhin, I.N., Mamyrin, B.A., Khabarin, L., 1976. The helium isotopes in thermal fluids, in: thermal and chemical problems of thermal waters. Int Assoc. Hydrol. Sci. 119, 17-33.

Poreda, R.J., Schilling, J.G., Craig, H., 1980. ${ }^{3} \mathrm{He} /{ }^{4} \mathrm{He}$ variations along the reykjanes ridge. Eos 61, 1158.

Poreda, R.J., Schilling, J.G., Craig, H., 1986. Helium and hydrogen isotopes in ocean ridge basalts north and south of Iceland. Earth Planet. Sci. Lett. 78, 1-17.

Poreda, R., Craig, H., Arnórsson, S., Welhan, J., 1992. Helium isotopes in Icelandic geothermal systems: I. ${ }^{3} \mathrm{He}$, gas chemistry, and ${ }^{13} \mathrm{C}$ relations. Geochim. Cosmochim. Acta 56 4221-4228.

Reed, M.H., 1982. Calculation of multicomponent chemical equilibria and reaction processes in systems involving minerals, gases and an aqueous phase. Geochim. Cosmochim. Acta 46, 513-528.

Reed, M.H., 1997. Hydrothermal alteration and its relationship to ore fluid composition. In: Barnes, H.L. (Ed.), Geochemistry of Hydrothermal Ore Deposits, 3rd ed. Wiley, New York, pp. 303-366.

Reed, M.H., 1998. Calculation of simultaneous chemical equilibria in aqueous-mineral-gas systems and its application to modeling hydrothermal processes. In: Richards, J. Larson, P. (Eds.), Techniques in Hydrothemal Ore Deposits Geology. Rev. Econ. Geol 10 pp. 109-124.

Reed, M.H., Spycher, N.F., 1984. Calculation of $\mathrm{pH}$ and mineral equilibria in hydrothermal water with application to geothermometry and studies of boiling and dilution. Geochim. Cosmochim. Acta 48, 1479-1490.

Sæmundsson, K., 1974. Fissure swarms and central volcanoes of the neovolcanic zones of Iceland. Geol. Soc. Am. Bull. 85, 495-504.

Sigvaldason, G.E., 1966. Chemistry of thermal waters and gases in Iceland. Bull. Volcanol. 29, 589-604.

Sigvaldason, G.E., Ellísson, G., 1968. Collection and analysis of volcanic gases at Surtsey, Iceland. Geochim. Cosmochim. Acta 32, 797-805.

Shinohara, H., Yoshikawa, S., Miyabuchi, Y., 2015. Degassing Activity of a Volcanic Crater Lake: Volcanic Plume Measurements at the Yudamari Crater Lake, Aso Volcano, Japan. In: Rouwet, D., Christenson, B., Tassi, F., Vandemeulebrouck, J. (Eds.), Volcanic Lakes. ISBN: 978-3-642-36832-5 (Print 978-3-642-36833-2 Online).

Symonds, R.B., Reed, M.H., 1993. Calculation of multicomponent chemical equilibria in gas-solid-liquid systems: calculation methods, thermochemical data and applications to studies of high-temperature volcanic gases with examples from Mount St Helens. Am. J. Sci. 293, 758-864.

Symonds, R.B., Gerlach, T.M., Reed, M.H., 2001. Magmatic gas scrubbing: implications for volcano monitoring. J. Volcanol. Geotherm. Res. 108, 303-341. 
Symonds, R.B., Janik, C.J., Evans, W.C., Ritchie, B.E., Counce, D.A., Poreda, R.J., Iven, M., 2003. Scrubbing masks magmatic degassing during repose at Cascade-Range and AleutianArc volcanoes. U.S. Geol. Surv. Open File Rep. 03-0435 22 pp.).

Spycher, N.A., Reed, M.H., 1988. Fugacity coefficients of $\mathrm{H}_{2} \mathrm{CO}_{2}, \mathrm{CH}_{4}, \mathrm{H}_{2} \mathrm{O}$ and $\mathrm{H}_{2} \mathrm{O}-\mathrm{CO}_{2}-\mathrm{CH}_{4}$ mixtures: a virial equation treatment for moderate pressures and temperatures applicable to calculations of hydrothermal boiling. Geochim. Cosmochim. Acta 52, 739-749.

Stefánsson, A., Arnórsson, S., 2000. Feldspar saturation state in natural waters. Geochim. Cosmochim. Acta 64, 2567-2584.

Stefánsson, A., Arnórsson, S., 2002. Gas pressures and redox reactions in geothermal fluids in Iceland. Chem. Geol. 190, 251-271.

Tamburello, G., Hansteen, T., Bredemeyer, S., Aiuppa, A., Tassi, F., 2014. Gas emissions from five volcanoes in northern Chile and implications for the volatiles budget of the central volcanic zone. Geophys. Res. Lett. 41, 4961-4969.

Thordarson, T., Larsen, G., 2007. Volcanism in Iceland in historical time: volcano types, eruption styles and eruptive history. J. Geodyn. 43, 118-152.

Ward, P.L., Björnsson, S., 1971. Microearthquakes, swarms, and the geothermal areas of Iceland. J. Geophys. Res. 76, 3953-3982.

Werner, C., Hurst, T., Scott, B., Sherburn, S., Christenson, B.W., Britten, K., Cole-Baker, J. Mullan, B., 2008. Variability of passive gas emissions, seismicity, and deformation during crater lake growth at White Island volcano, New Zealand, 2002-2006. J. Geophys. Res. 113, B01204. http://dx.doi.org/10.1029/2007JB005094.

Werner, C., Evans, W., Kelly, P., McGimsey, R., Pfeffer, M., Doukas, M., Neal, C., 2012. Deep magmatic degassing versus scrubbing: elevated $\mathrm{CO}_{2}$ emissions and $\mathrm{C} / \mathrm{S}$ in the lead-up to the 2009 eruption of Redoubt volcano, Alaska. Geochem. Geophys. Geosyst. 13, 1-18. http://dx.doi.org/10.1029/2011GC003794.

White, D.E., 1957. Thermal waters of volcanic origin. Geol. Soc. Am. Bull. 68, 1637-1658.

Wolery, T.J., 1979. Calculation of chemical equilibrium between aqueous solutions and minerals: the EQ3/6 software package. Report UCRL-52658. Lawrence Livermore National Laboratory, Livermore, California.

Wolery, T.J., 1992a. EQ3/6, A Software Package for Geochemical Modeling of Aqueous Systems: Package Overview and Installation Guide (Version 7.0). Report UCRL-MA110662 PT I. Lawrence Livermore National Laboratory, Livermore, California.

Wolery, T.J., 1992b. EQ3NR, A Computer Program for Geochemical Aqueous SpeciationSolubility Calculations: Theoretical Manual, User's Guide, and Related Documentation (Version 7.0). Report UCRL-MA-110662 PT III. Lawrence Livermore National Laboratory, Livermore, California.

Wolery, T.J., Daveler, S.A., 1992. EQ6, a computer program for reaction path modeling of aqueous geochemical systems: theoretical manual, user's guide and related documentation (version 7.0). Report UCRI-MA-110662 PT IV. Lawrence Livermore National Laboratory, Livermore, California.

Wolff-Boenisch, D., Gíslason, S.R., Oelkers, E.H., Putnis, C.V., 2004. The dissolution rates of natural glasses as a function of their composition at $\mathrm{pH} 4$ and 10.6, and temperatures from 25 to $74{ }^{\circ} \mathrm{C}$. Geochim. Cosmochim. Acta 68, 4843-4858. 